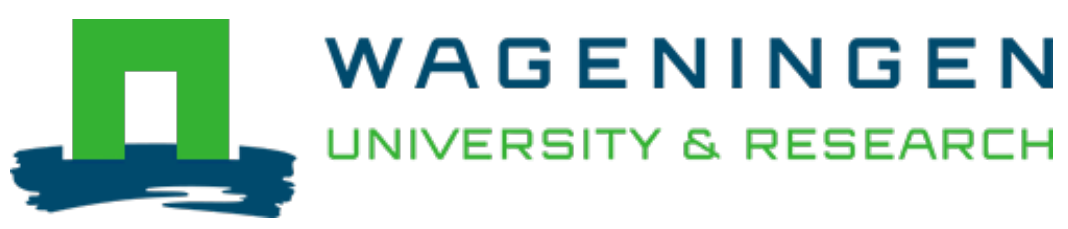

\title{
Near-daily discharge estimation in high latitudes from Sentinel-1 and 2: A case study for the Icelandic Pjórsá river
}

\author{
Remote Sensing of Environment \\ Brombacher, Joost; Reiche, Johannes; Dijksma, Roel; Teuling, Adriaan J. \\ https://doi.org/10.1016/j.rse.2020.111684
}

This article is made publicly available in the institutional repository of Wageningen University and Research, under the terms of article $25 \mathrm{fa}$ of the Dutch Copyright Act, also known as the Amendment Taverne. This has been done with explicit consent by the author.

Article 25 fa states that the author of a short scientific work funded either wholly or partially by Dutch public funds is entitled to make that work publicly available for no consideration following a reasonable period of time after the work was first published, provided that clear reference is made to the source of the first publication of the work.

This publication is distributed under The Association of Universities in the Netherlands (VSNU) 'Article $25 \mathrm{fa}$ implementation' project. In this project research outputs of researchers employed by Dutch Universities that comply with the legal requirements of Article $25 \mathrm{fa}$ of the Dutch Copyright Act are distributed online and free of cost or other barriers in institutional repositories. Research outputs are distributed six months after their first online publication in the original published version and with proper attribution to the source of the original publication.

You are permitted to download and use the publication for personal purposes. All rights remain with the author(s) and / or copyright owner(s) of this work. Any use of the publication or parts of it other than authorised under article $25 \mathrm{fa}$ of the Dutch Copyright act is prohibited. Wageningen University \& Research and the author(s) of this publication shall not be held responsible or liable for any damages resulting from your (re)use of this publication.

For questions regarding the public availability of this article please contact openscience.library@,wur.nl 


\title{
Near-daily discharge estimation in high latitudes from Sentinel-1 and 2: A case study for the Icelandic Djórsá river
}

\author{
Joost Brombacher $^{\mathrm{a}, *}$, Johannes Reiche ${ }^{\mathrm{b}, *}$, Roel Dijksma ${ }^{\mathrm{a}}$, Adriaan J. Teuling ${ }^{\mathrm{a}}$ \\ ${ }^{\text {a } H y d r o l o g y}$ and Quantitative Water Management Group, Wageningen University \& Research, The Netherlands \\ ${ }^{\mathrm{b}}$ Laboratory of Geo-Information Science and Remote Sensing, Wageningen University \& Research, The Netherlands
}

\section{A R T I C L E I N F O}

Edited by Menghua Wang

Keywords:

Discharge estimation

Hydrology

Sentinel-1

Sentinel-2

Near-daily

High latitudes

Machine learning

Iceland

\begin{abstract}
A B S T R A C T
Climate change is a threat to many high-latitude regions. Changing patterns in precipitation intensity and increasing glacial ablation during spring and summer have major influence on river dynamics and the risk of widespread flooding. To monitor these rapid events, more frequent discharge observations are necessary. Having access to near-daily satellite based discharge observations is therefore highly beneficial. In this context, the recently launched Sentinel-1 and 2 satellites promise unprecedented potential, due to their capacity to obtain radar and optical data at high spatial $(10 \mathrm{~m})$ and high temporal (1-3 days) resolutions. Here, we use both missions to provide a novel approach to estimate the discharge of the bjórsá (Thjórsá) river, Iceland, on a neardaily basis. Iceland, and many other high-latitude regions, are affected by frequent cloud-cover, limiting the availability of cloud-free optical Sentinel-2 data. We trained a Random Forest supervised machine learning classifier with a set of Sentinel-1 backscatter metrics to classify water in the individual Sentinel-1 images. A Sentinel-2 based classification mask was created to improve the classification results. Second, we derived the river surface area and converted it to the effective width, which we used to estimate the discharge using an at-astation hydraulic geometry (AHG) rating curve. We trained the rating curve for a six-month training period using in situ discharge observations and assessed the effect of training area selection. We used the trained rating curve to estimate discharge for a one-year monitoring period between 2017/10 and 2018/10. Results showed a KlingGupta Efficiency (KGE) of 0.831, indicating the usefulness of dense Sentinel-1 and 2 observations for accurate discharge estimations of a medium-sized (200 m width) high-latitude river on a near-daily basis (1.56 days on average). We demonstrated that satellite based discharge products can be a valuable addition to in situ discharge observations, also during ice-jam events.
\end{abstract}

\section{Introduction}

While the effects of climate change are now noticeable around the globe, they are particularly profound in high latitudes where temperatures have risen much faster than the global average (Bekryaev et al., 2010; Francis et al., 2017; Serreze et al., 2000). The impact of climate change on the hydrological cycle in the Arctic is visible in many ways. Over the years, the depth and duration of snow cover has decreased (Bach et al., 2018; Barnett et al., 2005), affecting the storage and release of meltwater (Cayan et al., 2001; Earman et al., 2006), while rain-induced erosion has increased due to higher winter temperatures (Kundzewicz et al., 2007; Lu et al., 2010). Additionally, the increase of permafrost thawing and the higher ablation rates of glaciers and icecaps accelerate the increase of discharge during spring and summer (Aðalgeirsdóttir et al., 2006; Déry et al., 2005; Flowers et al.,
2005; Jóhannesson et al., 2007; Osterkamp, 2007; Peterson et al., 2002). These effects and the resulting changes in discharge patterns of high-latitude river systems can be expected to influence freshwater availability and hydropower production (Abegg et al., 2007; Beniston, 2012; IPCC, 2013). The latter is especially important for countries like Iceland which rely heavily on this form of renewable energy (Icelandic Energy Authority, 2006). Since river discharge reflects many of the ongoing changes in the high latitudes, it is one of the important indicators of the impacts of climate change. Because many processes, like changing precipitation and glacial ablation patterns, have an immediate impact on river discharges, having access to frequent discharge observations is key to better understand these changing dynamics.

Traditionally, the discharge is derived from the combined knowledge on the cross-sectional shape of the river and the measured water level and flow speed (Harrelson et al., 1994). For natural rivers it is

\footnotetext{
${ }^{*}$ Corresponding authors.

E-mail addresses: joost.brombacher@gmail.com (J. Brombacher), johannes.reiche@wur.nl (J. Reiche).
} 
impractical to continuously observe the river cross-section and flow velocity, so often a stage-discharge relation is derived. This relation, also called a rating curve, is generated by comparing stage heights with a wide variety of discharge observations. However, prominent issues are unnoticed morphological changes in the river cross-section and the fact that the rating curve needs to be extrapolated for extreme discharges (Braca, 2008). Besides, the single and often narrow section of the river where the water level is observed does not include the complex dynamics of wetland and floodplain inundation (Alsdorf et al., 2007). In addition, for cold-climate catchments ice cover influences the hydraulic radius, which results in a decrease in river cross-sectional area. In some cases floating ice sheets form a natural dam (ice-jam), which increases the stage height and results in the discharge being overestimated (Beltaos and Prowse, 2001; Goulding et al., 2009; Herschy, 2009; Pagneux et al., 2011; Zufelt and Ettema, 2000). Due to the practical challenges and costs associated with routine discharge observations, the number of discharge observation stations has declined dramatically since the 1980s (Fekete and Vörösmarty, 2007). Therefore, there is a need for a reliable alternative to in situ discharge observations. The minimal temporal resolution required for these alternative observations depends on the shape of the streams hydrograph. In tropical regions where hydrographs show smooth and regular changes (Hidayat et al., 2017) it might be enough to have weekly or monthly observations. However, in Arctic regions due to sudden spring melt events the hydrographs can show large changes in the course of days, depending on the size and shape of the river basin. As a result, the required sampling strategy in a relatively small high-latitude river basins should ideally be in the order of a day as well (Alsdorf et al., 2007).

Satellite observations can complement current in situ discharge measurements and many studies have investigated the capacity of satellite-derived discharge estimations. The most common remote sensing based discharge estimations are derived from altimetry and river surface area observations (Alsdorf et al., 2007; Bjerklie et al., 2003; Durand et al., 2016). In addition, data assimilation techniques, where altimetry and surface area observations are coupled with statistical, hydraulic or hydrological models, are becoming more popular as well (Oubanas et al., 2018; Paris et al., 2016; Tourian et al., 2013).

Altimetry based discharge estimations rely on satellite platforms like the European Remote Sensing (ERS), Envisat, and the forthcoming Surface Water and Ocean Topography (SWOT) missions (Li et al., 2008; Milzow et al., 2011; Oubanas et al., 2018; Paris et al., 2016; Tourian et al., 2013; Tuozzolo et al., 2019). Most of the studies that use altimetry data to estimate the discharge use similar stage-discharge rating curves as for in situ discharge observations (Clement et al., 2017; Koblinsky et al., 1993). Although the altimetry observations itself are proven to be capable of obtaining height resolutions of 3-4 cm, such resolutions can only be reached when observing large bodies of water, while for river surfaces the accuracy is in the order of $10-50 \mathrm{~cm}$ (Alsdorf et al., 2007; Smith, 1997). This is caused by the fact that all altimeters are profiling instruments which only provide observations at a single spot. When a large water body is observed the different spot observations can be averaged to yield a high resolution, but for small rivers the number of observations is sparse, resulting in lower resolutions. However, due to the nature of altimeter observations, it is likely that a river will not even be observed during one completed orbit. Alsdorf et al. (2007) explain that for a generic 16-day orbit, $30 \%$ of the world's rivers are not being observed, which reduces the temporal resolution of the platform drastically. The future SWOT mission will deal with some altimeter issues (Oubanas et al., 2018; Tuozzolo et al., 2019). It will be capable of observing the extent of rivers wider than $100 \mathrm{~m}$ and the water level will be estimated with an accuracy of $10 \mathrm{~cm}$. The revisit period of SWOT will be 21 days. However, for each cycle 2 to 7 observations of the same location will be made, which translates to a temporal resolution of roughly 3 to 10 days, depending on the latitude (Biancamaria et al., 2016).
River surface area based discharge estimations rely on a simple relationship between the observed discharge and the effective width $\left(W_{e}\right)$ of a river, similar to the stage-discharge relation used for in situ observations. The result is a calibrated rating curve which can be used to estimate the discharge without needing additional discharge observations. To derive this relationship, one can use the so-called at-thestation hydraulic geometry (AHG), which was first described by Leopold and Maddock (1953). This widely accepted method has been successfully used by, among others, Ashmore and Sauks (2006), Boschetti et al. (1998), Brakenridge et al. (2005), Cooley et al. (2017), Gleason and Smith (2014), Hagemann et al. (2017), Hou et al. (2018), Huang et al. (2018), Pavelsky (2014), Sichangi et al. (2016), Smith et al. (1996), Smith (1997), Smith and Pavelsky (2008), Sun et al. (2010), Sun et al. (2018), and Xu et al. (2004). To derive the $W_{e}$, multiple satellites can be used, either in the optical (e.g. MODIS, Landsat, SPOT) or microwave (e.g. RADARSAT, ERS, JERS-1) part of the electromagnetic spectrum, each with their own advantages and disadvantages (Alsdorf et al., 2007; Boschetti et al., 1998; Cooley et al., 2017; Gleason and Smith, 2014; Hou et al., 2018; Huang et al., 2018; Pavelsky, 2014; Sichangi et al., 2016; Smith et al., 1996; Sun et al., 2010, 2018; Tarpanelli et al., 2013; Zaji et al., 2018). Optical multispectral observations are in some ways superior to radar imagery due to generally higher spatial resolutions, the observations of many bands, and the fact that these images are more intuitive to use. However, prominent issues for these satellites are cloud cover, smoke from forest fires, and observing water beneath flooded vegetation (Alsdorf et al., 2007; Mertes, 1997). Cloud cover is the biggest problem for optical satellites in Arctic regions (Ju and Roy, 2008; Probst et al., 2012), and especially so for Iceland which is often the source of low-pressure systems with persistent cloud cover as a consequence (Hanna et al., 2004). Radar-based imagery is more successful in reaching higher temporal resolutions due to their capacity to penetrate clouds and observe at night. However, whatever traditional freely available platform is used, due to cloud cover or a long revisit period the extent of the river could only be observed on a weekly to monthly basis.

In 2014 and 2016, as part of the ESA's Copernicus programme, Sentinel-1A and 1B C-band Synthetic Aperture Radar (SAR) satellites were launched. Because of this mission, for the first time both high spatial $(10 \mathrm{~m})$ and high temporal resolution (1-3 days) C-band SAR observations are freely available (Attema et al., 2007; ESA, 2012a). The actual temporal resolution differs per location and depends on many factors. At higher latitudes the temporal resolution generally increases due to the higher chance of overlapping paths caused by the smaller circumference of the earth (Torres et al., 2012). This effect is not visible for every continent, because ESA chooses to only store both ascending and descending images for high priority areas such as Europe, parts of Canada and the Northern Atlantic (Bauer-Marschallinger et al., 2018; ESA, 2012a; Torres et al., 2012). Fig. 1 shows that over Europe, on average, from 2017 until 2019, almost one image every day is acquired in Interferometric Wide (IW) swath mode, with increasing frequency towards the poles. Given this high spatial and temporal resolution, Sentinel-1 unlocks an unprecedented potential for estimating the discharge of high-latitude medium-sized river systems. However, up to now, no study has focussed on the potential of Sentinel-1 for generating near-daily discharge estimations in high-latitudes. Besides Sentinel-1, in 2015 and 2017 ESA also launched two high resolution $(10 \mathrm{~m})$ optical multi-spectral Sentinel-2 satellites which have the same orbital characteristics as Sentinel-1 (ESA, 2012b). Due to the short revisit period of the platform, Sentinel-2 is better capable of reaching higher temporal resolutions than comparable missions, but cloud cover prohibits neardaily observations. In this paper we study the potential of Sentinel-1 and 2 to estimate the discharge of a high-latitude medium-sized (50-400 m wide) river on a near-daily basis. We aim to answer the following research questions: 


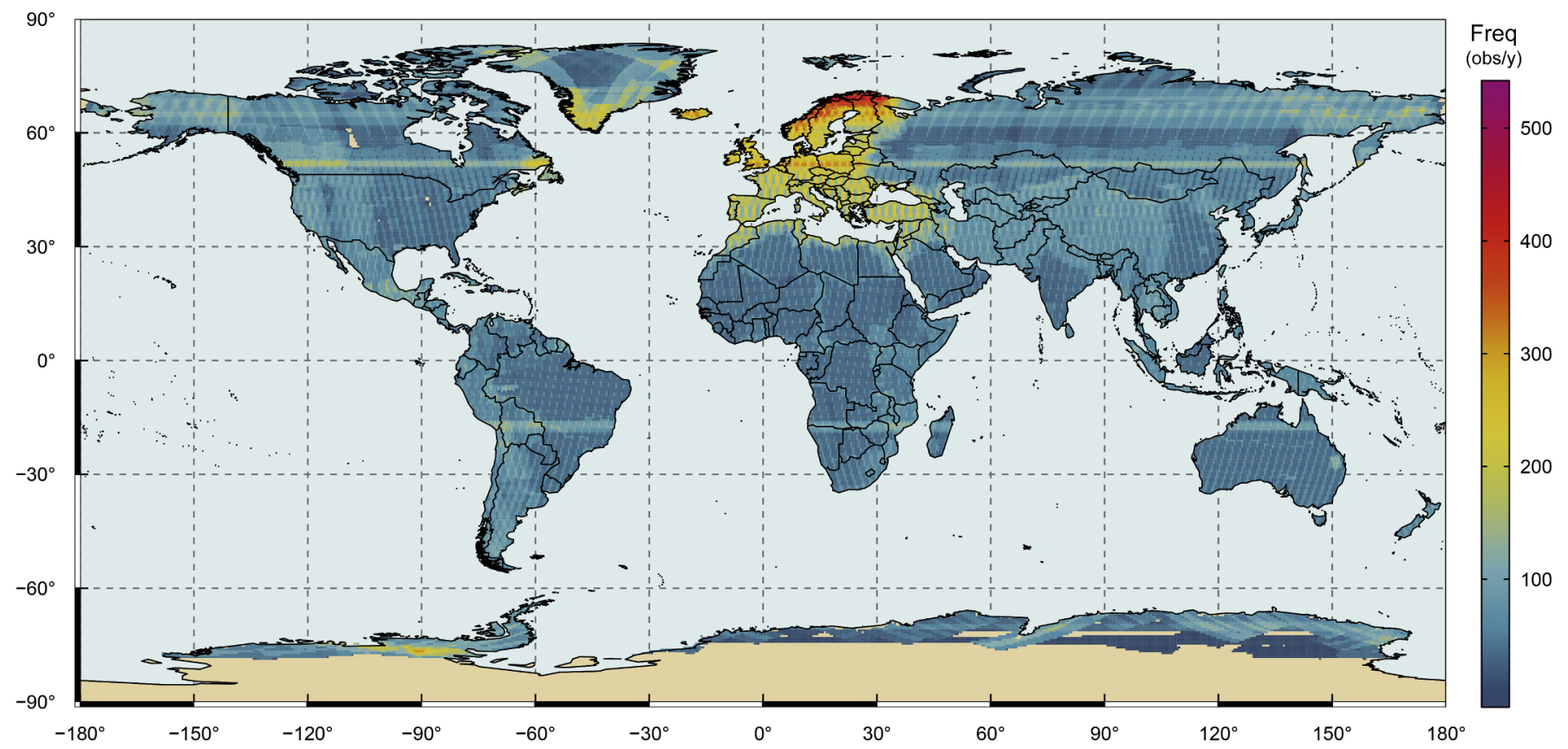

Fig. 1. The global average observation frequency of Sentinel-1 Level 1 Ground Range Detected (GRD) observations in Interferometric Wide (IW) swath mode derived from the Google Earth Engine database, calculated for the period between 2017/01/01 and 2019/06/01 and visualized at a 0.5-degree pixel size.

1. How accurate can we classify the surface of a medium-sized river using Sentinel-1, and can the accuracy be increased using Sentinel2 ?

2. Can we accurately estimate discharge from the near-daily river surface area observations, and what is the effect of the selected training area on the accuracy?

The study area of this research is the pjórsá (Thjórsá) river, Iceland, due to the ongoing and expected future impact of climate change on the region's hydrological cycle and the availability of discharge observations necessary for calibration and validation.

\section{Study area}

The pjórsá is located in the southwest of Iceland (Fig. 2). With a total length of $230 \mathrm{~km}$, a catchment area of $7530 \mathrm{~km}^{2}$, and a yearly mean discharge of $350 \mathrm{~m}^{3} / \mathrm{s}$ it is Iceland's longest and largest river (Gudmundsson, 2017; Hróðmarsson and Pórarinsdóttir, 2018; Ólafsdóttir and Ólafsson, 1999). The main source of water is overland flow due to high amounts of precipitation $(1500-3000 \mathrm{~mm} / \mathrm{y})$ and the melting of snow in combination with the presence of older relatively impermeable basalt formations. This results in a peak discharge during spring when the precipitation peak and snow melt rate is at its highest (Ólafsdóttir and Ólafsson, 1999). In summer, when ablation is highest, also the Hofsjökull and Vatnajökull glaciers are contributing significantly to the discharge. The pjórsá and its tributaries house six hydropower stations with a combined energy output of $935 \mathrm{MW}$ (Gudmundsson, 2017; Landsvirkjun, 2018). These power stations have a significant effect on the discharge since the flow in the river is not solely driven by precipitation and temperature, but also by energy demand of the Reykjavik area. For the pjórsá there is only one discharge measurement station available (station V320, see Fig. 2) (Icelandic Meteorological Office, 2011). The study area for this research stretches from this station roughly $15 \mathrm{~km}$ upstream and circumvents the river with a buffer distance of $500 \mathrm{~m}$. Five sub-areas with different landscape features were defined to assess the impact for discharge estimations, e.g. inner bank (A1), narrow stream (A2), large sandbars (A3), small sandbars (A4), and inundated land (A5).
Importantly for this research, the location of station V320 is known as an area where ice-jams can form (Eliasson and Gröndal, 2008). At this location, the river changes from a braided river of roughly $300 \mathrm{~m}$ wide into a narrow gorge of just $70 \mathrm{~m}$ wide (bottom left panel of Fig. 2). The ice-jam itself is typically about 3-4 km long and extends through the entire gorge (Eliasson and Gröndal, 2008). Ice-jams are disruptive for the flow of the river and reduce the hydraulic capacity of the channel upon which it develops, possibly resulting in widespread floods either upstream or downstream of the obstruction (Beltaos and Prowse, 2001; Goulding et al., 2009; Pagneux et al., 2010, 2011; Zufelt and Ettema, 2000). Due to the change in hydraulic capacity of the channel, the river stage is not representative for the discharge anymore, which causes discharge observations in the vicinity of the ice-jam to be incorrect. There are two different types of ice-jams, i.e. freeze-up and dynamic ice-jams. The first occurs when the surface of the river starts to freeze, in general in early winter. Dynamic ice-jams are caused by the breakup of ice sheets due to changes in weather conditions, i.e. temperatures above $0{ }^{\circ} \mathrm{C}$. These ice sheet fragments can get stuck at narrow sections or a sharp bend of the river. In a hydrograph the difference between the two can be spotted by looking at the rate at which the observed discharge increases. For freeze-up ice-jams the water level, and thus the observed discharge, rises steadily to the point when the ice-jam breaks and releases the stored water. Dynamic ice-jams show a faster response in the hydrograph and are usually short-lived. Because the study area is affected by both of these ice-jams, in this research we therefore also assess the impact of ice-jams on the possible benefit of remote sensing based discharge observations which are acquired away from the actual ice-jam.

\section{Data and methods}

An overview of the data and methods used in this research is shown in Fig. 3. We acquired near-daily Sentinel-1 C-band SAR images for the period between 2017/04/01 and 2018/10/01. Subsequently, cloud-free Sentinel-2 multi-spectral images were obtained. For this period, hourly in situ discharge observations were available. First, we calculated a set of backscatter metrics that were used to classify water from individual Sentinel-1 images using a Random Forest classifier (Section 3.2.1). 

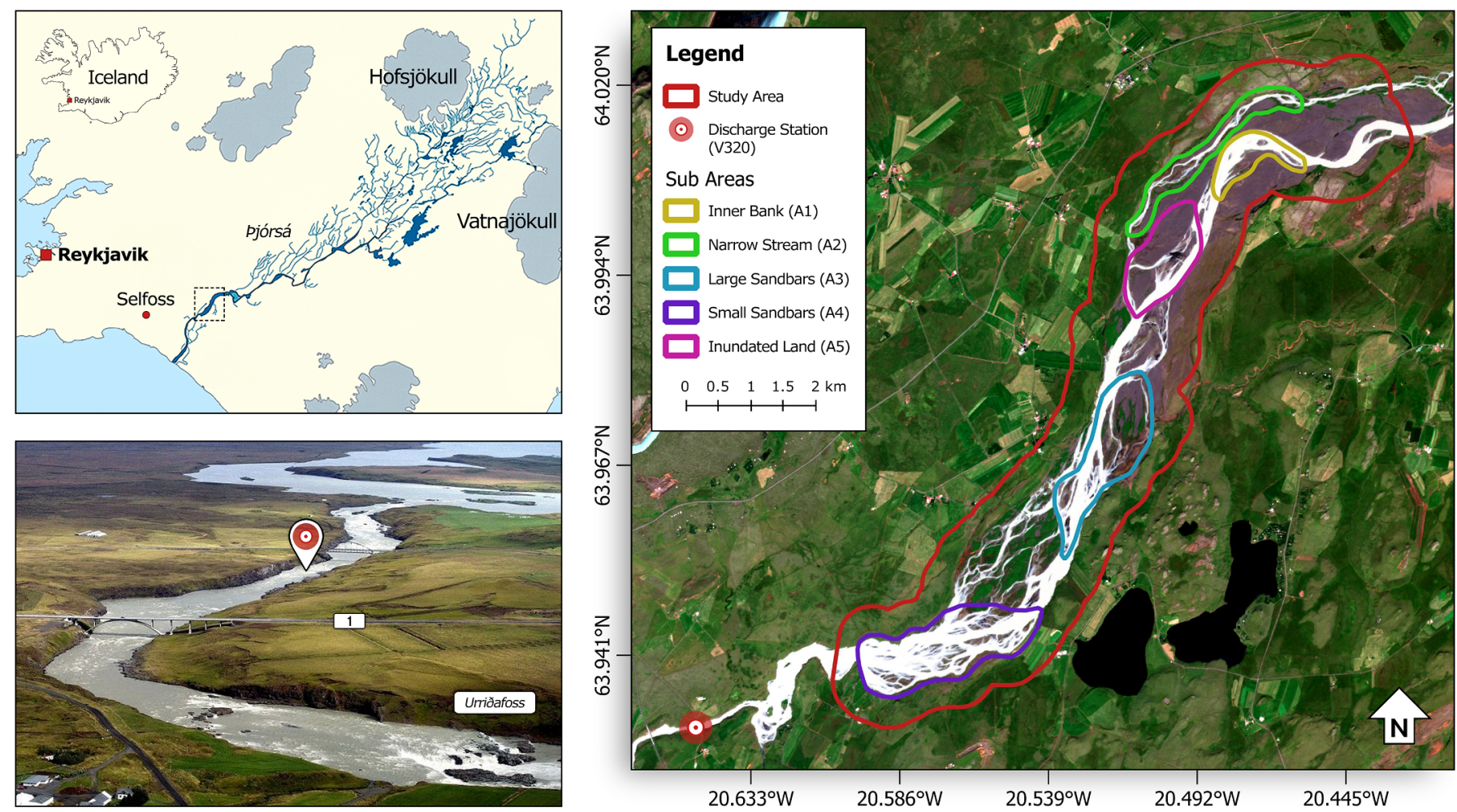

$20.633^{\circ} \mathrm{W}$

$20.586^{\circ} \mathrm{W}$

$20.539^{\circ} \mathrm{W}$

$20.492^{\circ} \mathrm{W}$

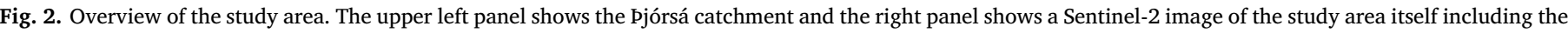

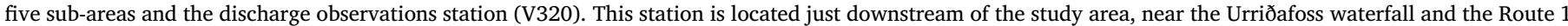

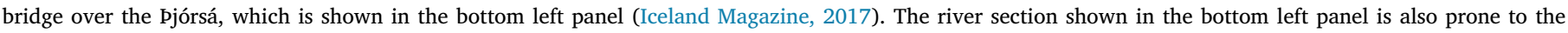
formation of ice-jams due to the sudden decrease in river width.

Second, we generated a classification mask based on multi-temporal Sentinel-2 images to increase the accuracy of the Sentinel-1 based water classifications. For this mask we used the Modified Normalized Difference Water Index (MNDWI) (Xu, 2006) to identify areas of stable land, stable water and dynamic areas using K-means density curve clustering (Section 3.2.2). We converted the water classifications to the effective width of the river that was subsequently used to estimate discharge through a rating curve. We used a six-month training period (2017/ 04-2017/10) to calibrate the rating curve with the observed discharge. We compared the modelling results for the different training areas. Finally, we used the rating curve of the best performing training area to estimate the discharge for the monitoring period between 2017/10/01 and 2018/10/01 (Section 3.2.3). To validate the water classifications and discharge estimations, very high $(3 \mathrm{~m})$ resolution Planet imagery and in situ discharge observations were used respectively (Section 3.2.4). The entire method is made available open-source allowing to reproduce results and main figures: https://github.com/ JoostBrombacher/NearDailyDischargeEstimations.

\subsection{Data}

\subsubsection{Sentinel-1}

We acquired Sentinel-1 C-band SAR images from Google Earth Engine (GEE) for the period between 2017/04/01 and 2018/10/01 (ESA, 2012a; Google Earth Engine, 2019). In GEE, Sentinel-1 images were pre-processed to backscatter coefficient (sigma nought and $\mathrm{dB}$ scale). In total, for the training and monitoring period combined, 358 dual-polarized ( $\mathrm{VV}$ and $\mathrm{VH}$ ) images with a pixel size of $10 \mathrm{~m}$ acquired in

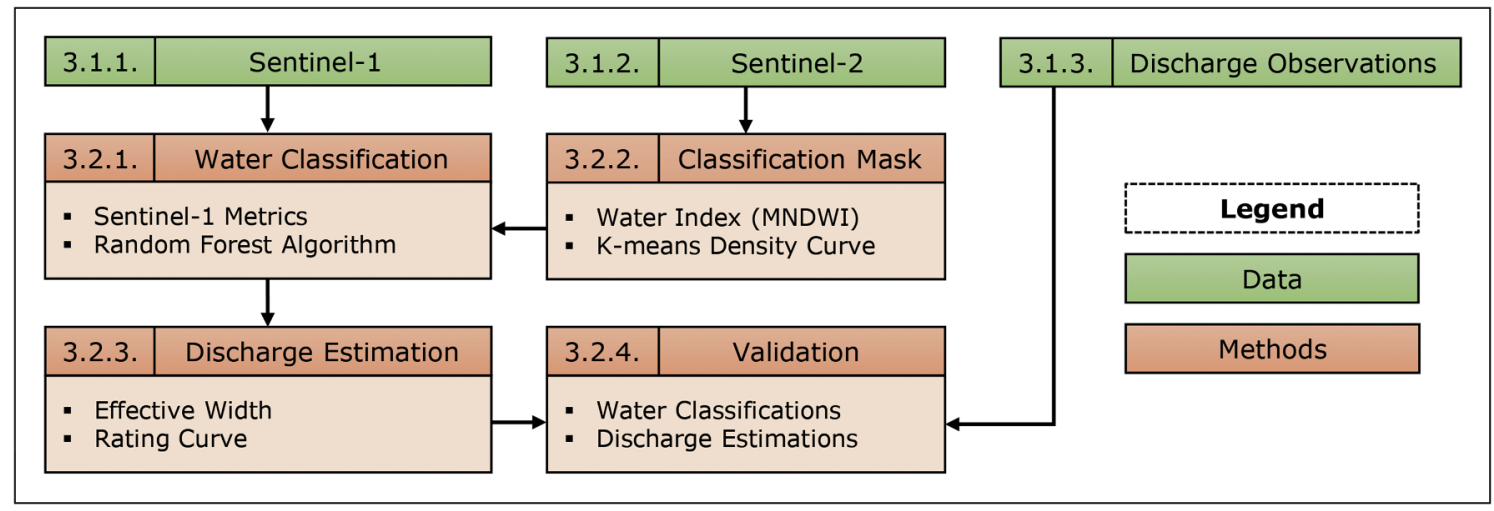

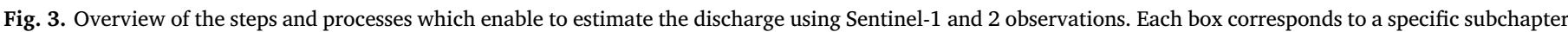

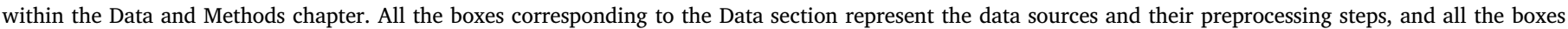
corresponding to the Methods section represent the different processes which describe the workflow of this research. 
Interferometric Wide (IW) swath mode were obtained. This corresponds to an average observation frequency of 1.53 days per image. Images obtained in IW mode have a swath size of $250 \mathrm{~km}$. For Iceland also dual-polarized $\mathrm{HH}$ and HV observations are available, but these were not used in this research. In addition to the standard pre-processing done in GEE, which includes thermal noise removal, radiometric calibration, and terrain correction (Google Earth Engine, 2019), we applied a Refined Lee filter to reduce the effect of radar speckle (Lemoine, 2017). Speckle is the result of the interference of incoherent signals, which is common for imaging systems that rely on coherent radiation, such as radar (Yommy et al., 2015). The resulting "salt and pepper" effect on radar images, due to the local amplification or attenuation of the signal, can be reduced using a speckle filter. The Refined Lee filter is based on the original Lee filter (Lee, 1986) and uses the K-Nearest Neighbor (KNN) algorithm instead of the standard Minimum Mean Square Error (MMSE) filtering criterion (Yommy et al., 2015).

\subsubsection{Sentinel-2}

We acquired 23 pre-processed and cloud-free optical Sentinel-2 images from GEE for the period between 2016 and 2018. This longer period was used because of the scarcity of cloud-free Sentinel-2 observations over Iceland. Sentinel-2 observes with 13 spectral bands ranging from the visible to the short-wave infrared (SWIR) part of the electromagnetic spectrum. The spatial resolution of the satellite is $10 \mathrm{~m}$ for the visible and near infrared (NIR) bands and $20 \mathrm{~m}$ for the red-edge and SWIR bands. Other bands which are used for monitoring water vapor, cirrus clouds, and coastal aerosols have a spatial resolution of $60 \mathrm{~m}$ (ESA, 2012b).

\subsubsection{Discharge observations}

Discharge observations from station V320 were made available by the Icelandic Meteorological Office and the National Power Company of Iceland, and were retrieved from the Hydrological Database no. 2018-1113/01 (Icelandic Meteorological Office, 2018). The dataset consists of hourly discharge observations and was derived from water-level observations with the use of a stage-discharge relationship. The Icelandic Meteorological Office checks the accuracy of the observed discharge, which was done until 13-11-2017. For the remainder of the dataset the observed discharge was not checked for major flaws in discharge observations, which are possibly caused by the formation of ice-jams.

\subsection{Methods}

\subsubsection{Sentinel-1 based water classification}

We classified water from individual Sentinel-1 images using a Random Forest classifier (Breiman, 2001; Liaw and Wiener, 2002). In addition to the original VV and $\mathrm{VH}$ backscatter images we derived a set of mono- and multi-temporal backscatter metrics (Table 1). The monotemporal backscatter metrics were derived by subtracting, adding, and dividing the original VV and VH backscatter images. Multi-temporal backscatter metrics were derived to identify the temporal dynamics of the river. The mean was calculated over tree consecutive images $(n-$ $1, n$, and $n+1$ ) for both polarizations and mainly reduced the signal noise of individual observations. The standard deviation was calculated for the observations of the entire training period for both polarizations, and mainly gave insight to which areas were most subjected to a changing land cover. Since no drastic changes during the training period were expected due to the limited abundance of vegetation in the area and the lack of snowfall, changes in land cover could be allocated to changes in river width. This helped to identify areas which are easily inundated, which increased the accuracy of the classifier.

As training data, six cloud-free Sentinel-2 images and six corresponding Sentinel-1 images were collected. The time difference between each set of Sentinel-1 and 2 image was in the order of a few hours to two days. However, more important than the time difference, the difference in discharge between each of these pairs of observations was checked to assure that both images corresponded to the same discharge
Table 1

Overview of the different Sentinel-1 backscatter metrics used for this research, including a brief description and example images focusing on sub-area A1.

\begin{tabular}{|c|c|c|}
\hline Metric & Description & Example \\
\hline VV & $\begin{array}{l}\text { VV-polarised } \\
\text { backscatter }\end{array}$ & \\
\hline VH & $\begin{array}{l}\text { VH-polarised } \\
\text { backscatter }\end{array}$ & \\
\hline $\mathrm{VV}-\mathrm{VH}$ & VV minus VH & \\
\hline $\mathrm{VV}+\mathrm{VH}$ & VV plus VH & \\
\hline $\mathrm{VV} / \mathrm{VH}$ & $\mathrm{VV}$ divided by VH & \\
\hline$\overline{\mathrm{VV}}$ & $\begin{array}{l}\text { Mean calculated } \\
\text { over the }\end{array}$ & \\
\hline$\overline{\mathrm{VH}}$ & $\begin{array}{c}\text { observations of } \\
n-1, n, \text { and } n+1\end{array}$ & \\
\hline$\sigma \mathrm{VV}$ & $\begin{array}{l}\text { Standard deviation } \\
\text { calculated over }\end{array}$ & \\
\hline$\sigma \mathrm{VH}$ & $\begin{array}{l}\text { six-month training } \\
\text { period }\end{array}$ & \\
\hline
\end{tabular}

conditions and inundation area. The images were collected during different seasons with discharges ranging between 280 and $480 \mathrm{~m}^{3} / \mathrm{s}$. Two of the six sets of images included snow and ice. Training points for water and land were collected from the Sentinel-1 images and checked using Sentinel-2 images. For each of the six Sentinel-1 images, 50 points were sampled for river areas and 150 points for land, respectively. This ratio roughly represented the distribution between water and land areas for the study area. In total 1200 training points were collected. The Random Forest classifier was optimized by setting the number of trees (ntree) to 500 and calibrating the mtry parameter using tuneRF function of the randomForest R-package (Strobl et al., 2008). We assessed the variable importance of the backscatter metrics by calculating the Mean Decrease Gini (MDG). MDG expresses the purity of the nodes at the end of the decision tree when leaving out a specific metric. The larger the MDG value, the more important the metric for the Random Forest classifier (Calle and Urrea, 2010; Han et al., 2017).

\subsubsection{Sentinel-2 based classification mask}

Many researches already exploited the possibility of estimating the discharge using optical remote sensing observations due to their generally high spatial resolution and the observation of many different bands (Cooley et al., 2017; Gleason and Smith, 2014; Huang et al., 2018; Pavelsky, 2014; Sichangi et al., 2016; Smith and Pavelsky, 2008; Sun et al., 2018). However, as mentioned earlier, the poor temporal resolution of most of the used platforms make it difficult to generate a dense discharge time series. Sentinel-1 is not as powerful as optical satellites for water monitoring and due to the noisy nature of the individual C-band SAR observations classification errors exist in the Sentinel-1 based water classifications (Manakos et al., 2019; Tavares et al., 2019). To fuse the high (water classification) accuracy of optical sensors with the high temporal resolution of Sentinel-1, we generated a Sentinel-2 based classification mask to eliminate errors in the Sentinel-1 based water classifications for areas where the land cover (water or land) is stable and not affected by river discharge dynamics (Fig. 4). Examples of such areas are the middle of the river which is always flooded and representing stable water, and overgrown or elevated areas 

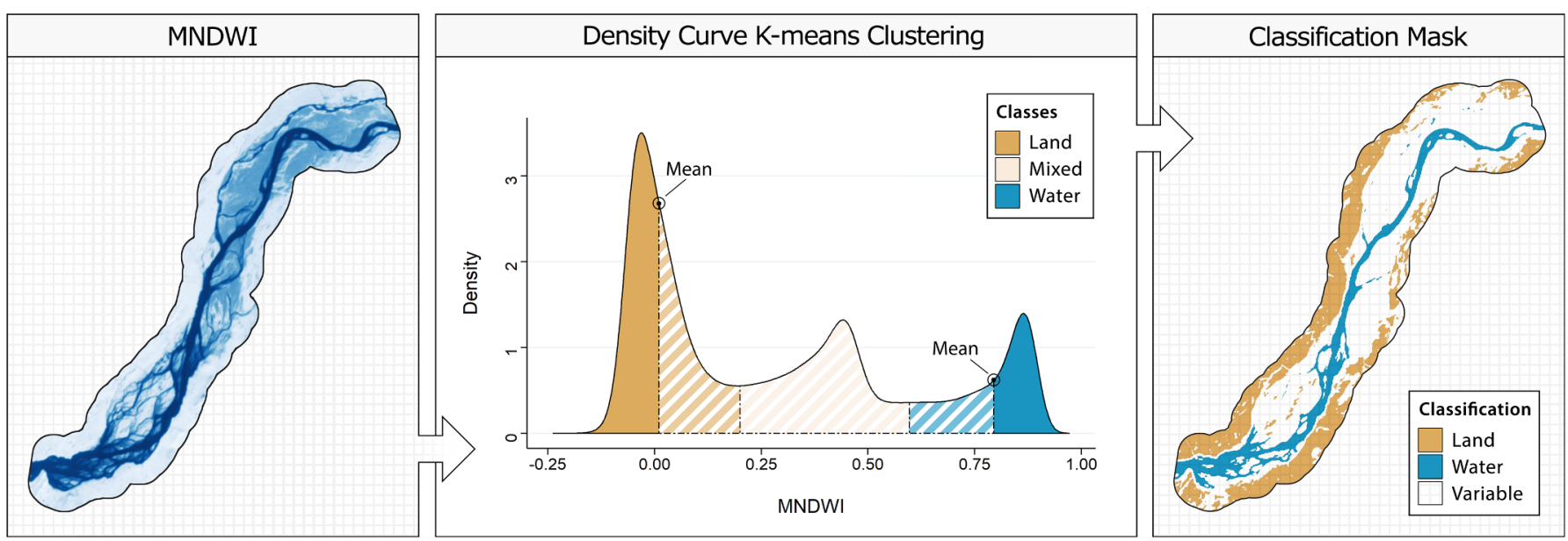

Fig. 4. The approach of creating the classification mask. First the MNDWI is calculated over the mean of 23 cloud-free Sentinel-2 images (left). The histogram of the MNDWI is then converted to a density curve and three different classes (water, land, and mixed) are derived by using K-means clustering. The threshold values are derived by calculating the mean MNDWI values for the water and land clusters (center). The result is a classification mask where all the white (striped) areas represent variable land cover, while the brown and blue areas have a fixed classification (right).

which are rarely flooded and representing stable land. To get a representative classification mask, a wide variety of inundation areas corresponding to low and high flow should be included in the set of optical images. In our research, we generated the classification mask based on the MNDWI calculated for 23 cloud-free Sentinel-2 observations. The MNDWI (Eq. (1)) is used since it is one of the most robust optical indices for classifying water features (Feyisa et al., 2014; McFeeters, 2013; Qiao et al., 2012; Xu, 2006; Yang et al., 2017).

MNDWI $=\frac{\text { Green }- \text { SWIR }}{\text { Green }+ \text { SWIR }}$

The MNDWI ranges between -1 and 1 , with high values corresponding to water and low values to land. The MNDWI is calculated using Sentinel-2's green (Band 3 at $559.8 \mathrm{~nm}$ ) and short-wave infrared (SWIR) bands (Band 11 at $1613.7 \mathrm{~nm}$ ). Fig. 4 visualizes the process of generating the classification mask. For the study area, the histogram of the MNDWI showed a typical trimodal distribution. The left peak represents land, the right peak water and the center peak mixed land cover. We first derived the density curve from the histogram and used K-means clustering (MacQueen, 1967) to separate these three classes. Next, the mean MNDWI values of the water and land clusters were used as thresholds values to identify stable land (MNDWI $<0.01$ ) and stable water pixel (MNDWI > 0.79). Every pixel with an MNDWI value that lies between these two thresholds was excluded from the classification mask and its land cover was derived from Sentinel-1 images that were classified with Random Forest.

\subsubsection{Discharge estimation}

To be able to estimate the discharge, the water surface area was calculated from the individual water classifications using the following equation:

$A_{w}=\frac{P_{w} A_{\text {total }}}{P_{\text {total }}}$

where $P_{w}$ and $A_{w}$ represent the number of pixels and the size of the area $\left(\mathrm{m}^{2}\right)$ classified as water, and $P_{\text {total }}$ and $A_{\text {total }}$ represent the total number of pixels and the total size of the area $\left(\mathrm{m}^{2}\right)$, respectively. From the water surface area the effective width was calculated for every image. The effective width is derived by dividing the water surface area $\left(A_{w}\right)$ in $\mathrm{m}^{2}$ by the length of the specific river section $(L)$ in m, as shown in Eq. (3).

$W_{e}=\frac{A_{w}}{L}$

$L$ was derived from hand drawn lines reaching from the inlet to the outlet of each sub-area, roughly following the center of the river. For the braided sections of the river we used a single line as well. Since these lines were drawn by hand, the effective width does not $100 \%$ reflect the actual width of the river for each sub-area. However, in this research we were not interested in the actual river width itself, but in the discharge, whose estimates will not become more or less accurate when using more precise approaches for extracting the river length. Instead, the accuracy depends more on the accuracy of the river surface area observations.

After calculating $W_{e}$ we derived the rating curve which described the relationship between the effective width and the discharge. Due to the nature of a rating curve, in situ discharge observations are needed to calibrate the rating curve parameters. Leopold and Maddock (1953) derived three different functions which describe the so-called at-a-station hydraulic geometry (AHG). One of these functions describes the relationship between the effective width and the discharge as a power function and is used by many studies to generate remote sensing based discharge estimations (Alsdorf et al., 2007; Ashmore and Sauks, 2006; Boschetti et al., 1998; Brakenridge et al., 2012; Cooley et al., 2017; Gleason and Smith, 2014; Hagemann et al., 2017; Hou et al., 2018; Huang et al., 2018; Pavelsky, 2014; Sichangi et al., 2016; Smith and Pavelsky, 2008; Smith et al., 1996; Sun et al., 2010, 2018; Xu et al., 2004; Zaji et al., 2018). The function is formulated as follows:

$W_{e}=a Q^{b}$

where $W_{e}$ is the effective width (m), $Q$ is the discharge $\left(\mathrm{m}^{3} / \mathrm{s}\right)$, and $a$ and $b$ are empirically derived coefficients which define the relationship between the discharge and the effective width. These coefficients are affected by many different factors like the slope, the shape of the river, the flow speed, and so on. Leopold et al. (1995) found that on a global average the $b$-exponent has a value of 0.26 and also other studies tried to link these coefficients to hydraulic geometries of many rivers in different climates (Jowett, 1998; Park, 1977; Rhoads, 1991; Smith and Pavelsky, 2008). However, the exchangeability of the derived coefficients from one catchment to another is not proven (Alsdorf et al., 2007). To determine what the optimal values for coefficients $a$ and $b$ for the pjórsá were, the rating curve was calibrated for a six-month training period (2017/04-2017/10) where both the effective width and the discharge were observed. The rating curve was derived for all the different training areas (study area and sub-areas) while excluding and including the classification mask. In the end, the rating curve of the best performing training area was used to estimate the discharge for yearlong monitoring period (2017/10-2018/10). 


\subsubsection{Validation}

Besides Sentinel-2, many different platforms carry optical instruments which can be used for the validation of the Random Forest classifier. However, they either have a lower spatial resolution (like Landsat and MODIS), or they are commercial products which often charge a lot of money for their service. Planet is an example of the latter, and provides very high resolution $(3 \mathrm{~m})$ imagery on a daily basis. Due to the highly dynamic behavior of the bjórsá, the cloud-cover intensity over Iceland, and the differences in satellite orbits, acquiring both a cloud-free optical image and a Sentinel-1 images which both represent the same discharge conditions was highly challenging. For this research we acquired one cloud-free Planet image from 2017/08/ 20 . The closest Sentinel-1 observation was obtained $28 \mathrm{~h}$ earlier. Due to the river being relatively stable over this particular period, the difference in discharge was only $6 \mathrm{~m}^{3} / \mathrm{s}$, making both images suitable candidates to validate the classifier. For this Sentinel-1 image $88.5 \%$ of the area was classified as land and the other $11.5 \%$ as water. To validate this image a dataset of 1500 points was created. In order to obtain a dataset of equal density for water and land, 173 water points and 1327 land points were randomly selected according to this 11.5/88.5 ratio. The classification of each sample point was then checked for being water or land with the Planet image. We finally calculated the overall, user's, and producer's accuracy using the resulting confusion matrix (Banko, 1998; Congalton and Green, 2009; Radoux and Bogaert, 2017; Sammut and Webbs, 2011). The overall accuracy (Eq. (5a)) indicates for all classes combined what percentage of the points are being classified correctly. The user's accuracy (Eq. (5b)) represents the reliability of the classifier, by informing the user how well the classifier represents each class. The producer's accuracy (Eq. (5c)) also tells how well each class is classified, but it refers to the proportion of observed features which are present in reality but not classified correctly.

$$
\begin{aligned}
& \text { Overall accuracy }=\frac{T_{P}+T_{N}}{T_{P}+T_{N}+F_{P}+F_{N}} \\
& \text { User's accuracy }=\frac{T_{P}}{T_{P}+F_{N}}
\end{aligned}
$$

Producer's accuracy $=\frac{T_{P}}{T_{P}+F_{P}}$

In binary classifications, such as our water/land classification, four different outcomes within the confusion matrix exist, i.e. (i) True Positives $\left(T_{P}\right)$, (ii) False Positives $\left(F_{P}\right)$, (iii) False Negatives $\left(F_{N}\right)$, and (iv) True Negatives $\left(T_{N}\right)$ (Radoux and Bogaert, 2017; Sammut and Webbs, 2011). When calculating the user's or producer's accuracy of the water class, $T_{P}$ represents pixels that are correctly classified as water, $F_{P}$ represents land pixels that are classified as water, $F_{N}$ represents water pixels that are classified as land, and $T_{N}$ represents pixels that are correctly classified as land.

To investigate the accuracy of the calculated effective width and the estimated discharge, the Root Mean Square Error (RMSE) and KlingGupta Efficiency (KGE) (Gupta et al., 2009) were calculated. The RMSE was calculated both for the difference between the observed effective width and the estimated effective width and for the difference between the observed discharge and the estimated discharge. The KGE was only calculated for the latter. Due to the nature of the RMSE, outliers and large errors are emphasized (Willmott and Matsuura, 2005). The RMSE is calculated as follows:

$\mathrm{RMSE}=\sqrt{\frac{1}{n} \sum_{i=1}^{n}\left(s_{i}-o_{i}\right)^{2}}$

where $s_{i}$ and $o_{i}$ are the simulations and observations for moment $i$, and $n$ represents the number of observations. Like the RMSE, the KGE is a measure to analyze the accuracy of a prediction compared to the observation. However, the KGE is designed for time series analysis and ranges from $-\infty$ to 1 , with 1 being a perfect fit. When the KGE is 0 , the mean of the predictions is the same as the mean of the observations. The KGE is preferred above the more traditional Nash-Sutcliffe efficiency (NSE) since the KGE is proven to be more tailored for regressing simulations against observations. The KGE is build using the correlation coefficient $(r)$, the variability error $(\alpha)$, and the bias error $(\beta)$ as described in Eq. (7) (Gupta et al., 2009).

$$
\begin{gathered}
\mathrm{KGE}=1-\sqrt{(r-1)^{2}+(\alpha-1)^{2}+(\beta-1)^{2}} \\
\text { where: } r=\frac{\operatorname{cov}_{s o}}{\sigma_{s}-\sigma_{o}}, \alpha=\frac{\sigma_{o}}{\sigma_{s}}, \beta=\frac{\mu_{s}-\mu_{o}}{\sigma_{o}}
\end{gathered}
$$

$\operatorname{cov}_{s o}$ represents the covariance between the simulations and observations, $\sigma_{s}$ and $\sigma_{o}$ represent the standard deviations of the simulations and observations, and $\mu_{s}$ and $\mu_{o}$ represent the mean of the simulations and observations. In order to create a confidence interval around the derived rating curve, bootstrapping was applied. The bootstrap method is created by Efron (1979) and is a process where multiple times a dataset is randomly resampled with replacement to be able to calculate statistics that cannot be calculated with the original dataset. In our case, the rating curve (Eq. (4)) that was defined for a specific training area was recalculated 500 times by randomly resampling the dataset of the calculated effective width. With these 500 rating curves also the discharge was estimated 500 times, so we could calculate the $90 \%$ confidence intervals for the estimated discharge as well.

\section{Results}

\subsection{Water classification and classification mask}

The results for the water classification are shown in Table 2 and Fig. 5. The overall accuracy excluding and including the classification mask was $91.5 \%$ and $92.5 \%$, respectively. However, due to the difference in number of samples for water and land, this is not a proper metric to use. The user's and producer's accuracy provide more accurate and detailed information on the accuracy. The user's accuracy for both the water and land classes were already high for the unmasked validation image $(89.6 \%$ and $91.9 \%$ respectively), but increased slightly when adding the classification mask $(91.0 \%$ and $92.8 \%$ respectively). For the producer's accuracy the difference between the water and land class was higher, with an initial producer's accuracy of $71.6 \%$ and $97.5 \%$ for the water and land classes respectively. When including the classification mask, the producer's accuracy of the water class increased to $75.1 \%$, while the producer's accuracy of the land class only increased with $0.2 \%$. The overall lower producer's accuracy of the water class was mainly visible for the smaller branches of the river which were mostly not classified as water (Fig. 5). Fig. 6 shows the MDG calculated for the backscatter metrics used in the Random Forest classifier. VV was the most important metric for the classifier, followed by $\sigma \mathrm{VV}$ and VV/VH.

Apart from $\mathrm{VV}$ and $\mathrm{VH}$, the other metrics were of little importance for the classification process. Overall, the VV metrics were more dominant for the Random Forest classifier than the VH metrics.

\section{Table 2}

\begin{tabular}{|c|c|c|c|c|}
\hline & \multicolumn{2}{|c|}{ Unmasked } & \multicolumn{2}{|l|}{ Masked } \\
\hline & Water & Land & Water & Land \\
\hline User's accuracy & $89.6 \%$ & $91.9 \%$ & $91.0 \%$ & $92.8 \%$ \\
\hline Producer's accuracy & $71.6 \%$ & $97.5 \%$ & $75.1 \%$ & $97.7 \%$ \\
\hline Overall accuracy & \multicolumn{2}{|c|}{$91.5 \%$} & \multicolumn{2}{|c|}{$92.5 \%$} \\
\hline
\end{tabular}

The overall, user's, and producer's accuracies calculated for the classified validation image (2017/08/19) both excluding (unmasked) and including (masked) the classification mask. 

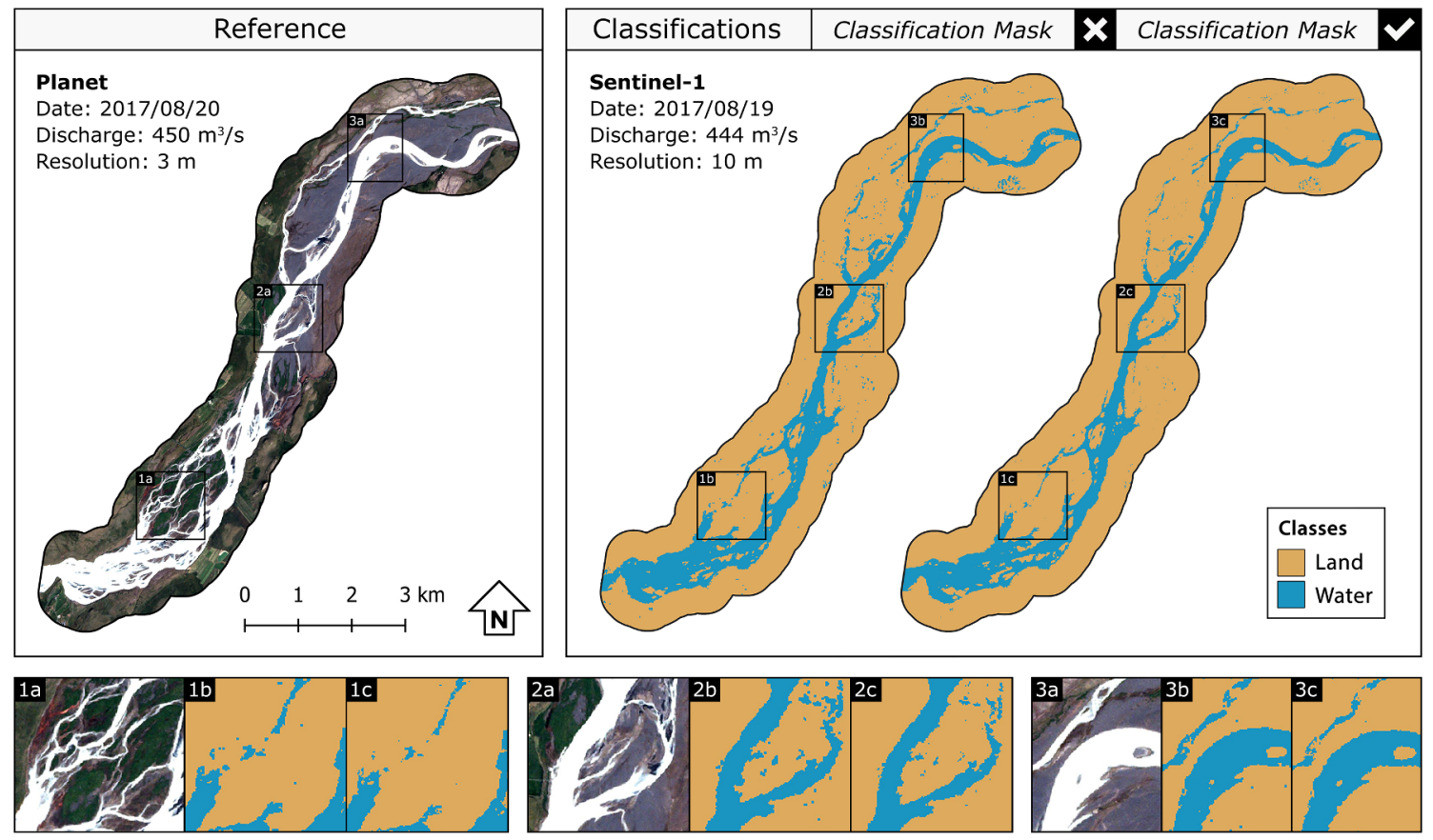

Fig. 5. The reference very high resolution Planet image (RGB) compared to the classified validation image (2017/08/19) either excluding (left) or including (right) the classification mask. Note the large river features being classified accurately, while smaller streams seem difficult to classify correctly.

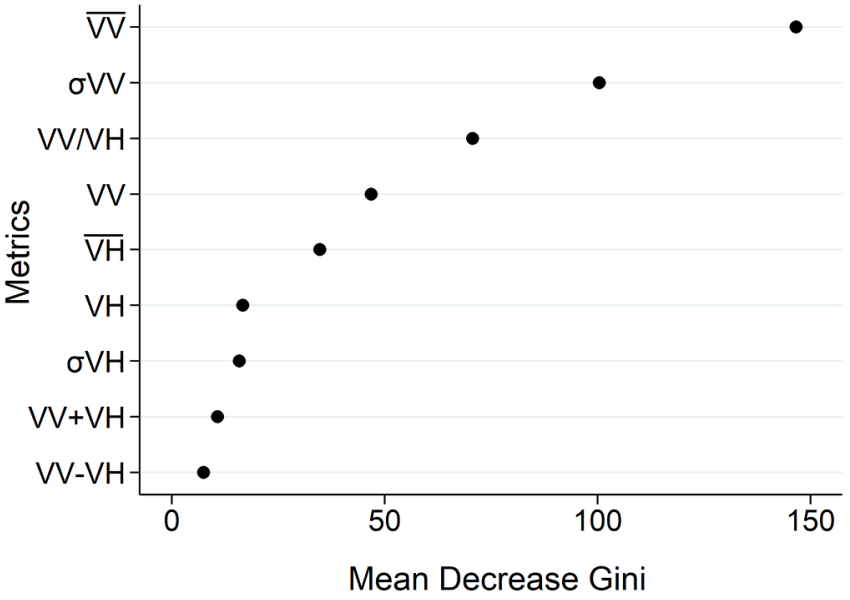

Fig. 6. The Mean Decrease Gini (MDG) of the Random Forest classifier calculated for the two original $(\mathrm{VV}$ and $\mathrm{VH})$ and seven derived backscatter metrics (Table 1).

\subsection{Discharge estimation}

Table 3 shows the results of the KGE calculated for the estimated discharge compared to the observed discharge for the training period. In comparison to the difference in accuracy between the classifications when including and excluding the classification mask (Table 2 and Fig. 5), the difference in KGE for the estimated discharge was significantly larger. Table 3 and Fig. 7 show that the worst performing training area was sub-area A2, which included a narrow stream, showing where the limits of Sentinel-1's $10 \mathrm{~m}$ spatial resolution lie for accurate river dynamic observations. The other training areas yielded better results, with the study area and sub-areas A3, A4, and A5 yielding roughly the same KGE when the classification mask was included (0.422 -0.463). Sub-area A1, which included the inner bank, yielded the highest accuracy with a KGE of 0.787 . The RMSE calculated for this sub-area was $51.5 \mathrm{~m}^{3} / \mathrm{s}$, which is roughly $14.7 \%$ of the yearly average discharge. For all the training areas the $90 \%$ confidence
Table 3

The KGE of the estimated discharge for the training period and all the training areas, both excluding (unmasked) and including (masked) the classification mask.

\begin{tabular}{lll}
\hline Training areas & Unmasked & Masked \\
\hline Study area (SA) & 0.230 & 0.456 \\
Inner bank (A1) & 0.400 & 0.787 \\
Narrow stream (A2) & -0.667 & -0.654 \\
Large sandbars (A3) & 0.235 & 0.463 \\
Small sandbars (A4) & 0.133 & 0.428 \\
Inundated land (A5) & 0.292 & 0.422 \\
\hline
\end{tabular}

interval bands increased for high and low discharge estimations due to the lack of extreme discharge observations during the training period. Due to sub-area A1 yielding the highest KGE for the estimated discharge during the training period, its rating curve was used to estimate the discharge for the monitoring period of $2017 / 10$ to $2018 / 10$. The result of the estimated discharge for this period including the residuals is shown in Fig. 8. The KGE of the estimated discharge for sub-area A1 increased from 0.787 during the training period, to 0.831 for the monitoring period. Overall, Fig. 8 shows that the seasonal trend with low discharges in winter and high discharges in summer was well represented. In addition, most of the observed discharge peaks were visible for the estimated discharge as well. During winter, however, some observed discharge peaks were not estimated accurately. If the winter period (November-March) is excluded from the analysis the KGE increases to 0.867 and the RMSE decreases to $46.7 \mathrm{~m}^{3} / \mathrm{s}$. The winter period itself yields a KGE of 0.241 and a RMSE of $59.6 \mathrm{~m}^{3} / \mathrm{s}$.

\section{Discussion}

In this research, we proposed a method aimed at estimating the discharge of a gauged medium-sized, high-latitude river and on a neardaily basis, using high spatial and high temporal resolution Sentinel-1 and 2 observations. We translated near-daily Sentinel-1 observations to water classifications using Random Forest. We showed that implementing additional backscatter metrics was beneficial for the 

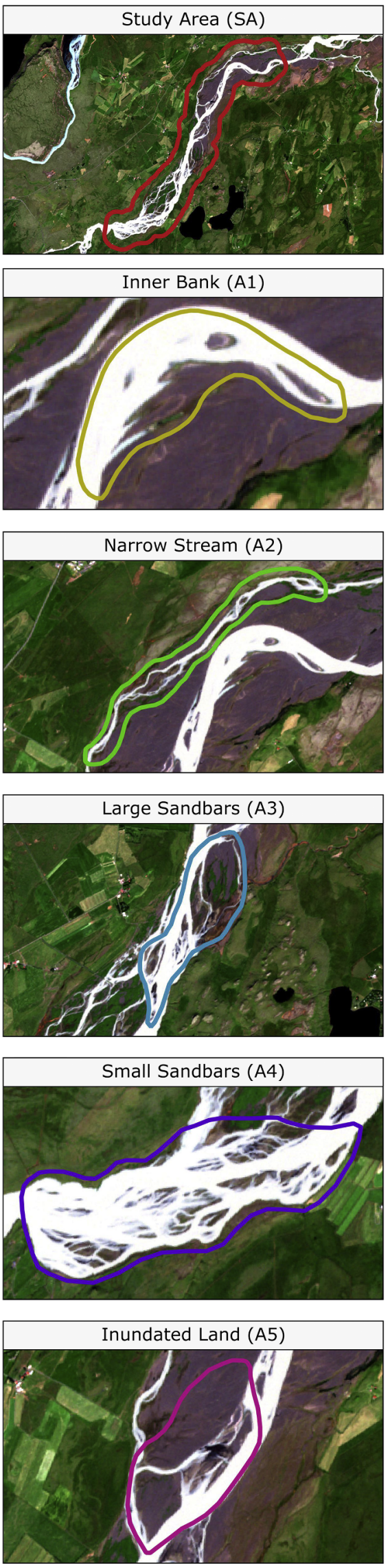
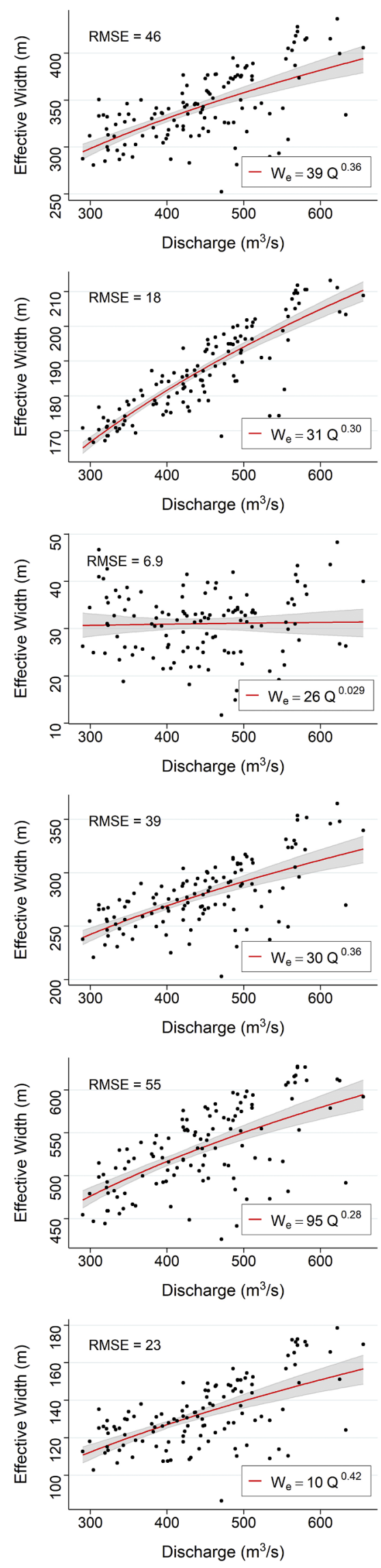

- $90 \% \mathrm{Cl} \cdot$ Observed - Rating Curve
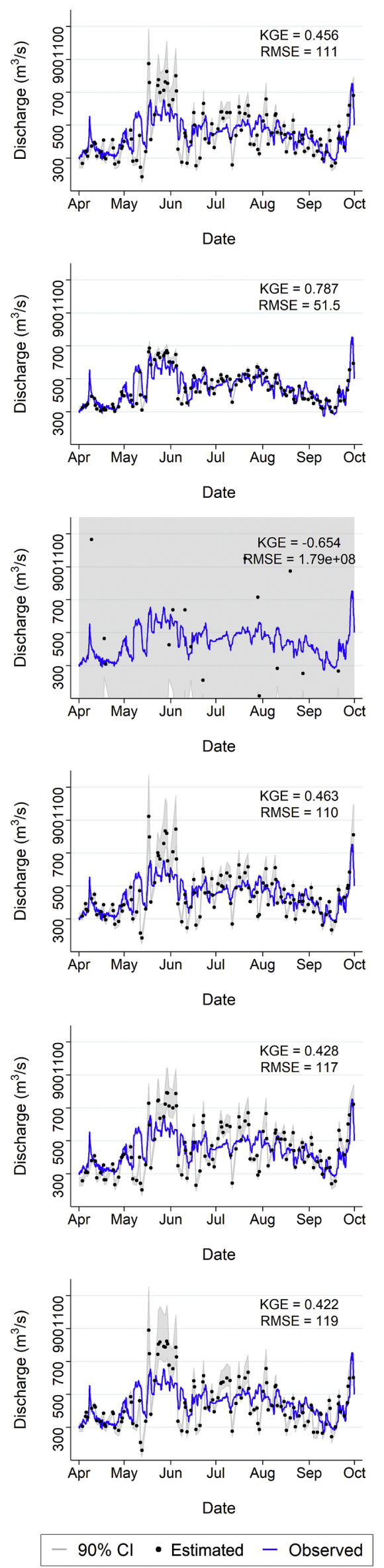

(caption on next page) 


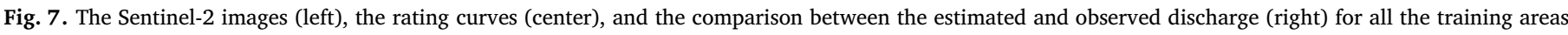

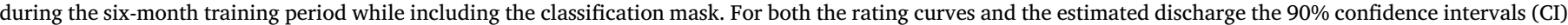
are provided.

classification accuracy and that including the Sentinel-2 based classification mask was key for generating accurate discharge estimations. Due to the capacity of Sentinel-1 to observe through clouds, on average the discharge could be estimated once every 1.56 days, showing the potential of dense C-band SAR satellite observations for discharge estimation in fast responding high-latitude catchments. The following sections provide a detailed discussion of the results.

\subsection{Training area selection}

We showed that training area selection is crucial for accurate discharge estimation. The five sub-areas used in this research gave insight into the effect of different features in the landscape (Table 3 and Fig. 7). Gently sloping features like inner banks and large isolated sandbars, and sufficient river width (100-200 m) were proven to be beneficial for the accuracy of the estimated discharge. Narrow streams ( $\leq 50 \mathrm{~m}$ ) are to be avoided, due to Sentinel-1 not being able to accurately observe river dynamics at such a small scale.

\subsection{Water classifications}

We showed that implementing additional backscatter metrics is key for generating accurate water classifications. The MDG (Fig. 6) showed that the VV and $\sigma \mathrm{VV}$ metrics were crucial for the Random Forest classifier, and that overall the individual $\mathrm{VH}$ backscatter metrics were less important for the model. The success of these metrics was the balance between smoothing the noisy original $\mathrm{VV}$ and $\mathrm{VH}$ observations while preserving the river dynamics in the backscatter signals. The $\sigma \mathrm{VV}$ and $\sigma \mathrm{VH}$ metrics were calculated for the six-month training period and gave insight where the backscatter intensity was most likely to change.

By using the Sentinel-1 based backscatter metrics, we showed that we were able to accurately classify water using the Random Forest supervised machine learning algorithm. Once the algorithm is trained thoroughly, one could easily implement the classifier to classify water for different study areas and potentially create a standardized water classification algorithm. However, there is still room for improvement. For example, Random Forest does not compare neighboring pixels for its classification process. With other classification techniques one could also implement knowledge on the topography and the stream network (Shen et al., 2019).

Although the water classifications were proven to be accurate for the validation image (Table 2 and Fig. 5), there are some threats when using Sentinel-1 based backscatter metrics for water classifications. For example, wind roughing is a known issue for C-band SAR observations. Due to the relatively short wavelength $(5.5 \mathrm{~cm})$ of the C-band antenna, for large rivers the backscatter intensity can change due to changes in wave heights (Alsdorf et al., 2007). For smaller rivers, or rivers with a high flow velocity, standing waves can affect the backscatter intensity as well. These changes potentially decrease the accuracy of the water classifier. Ideally an L-band radar should be used for water surface classifications since the longer wavelengths do not interfere with small scale waves as much as C-band signals do. Additionally, L-band sensors are better capable of monitoring water surfaces beneath dense vegetation (Alsdorf et al., 2007; Hidayat et al., 2017). Unfortunately, today no

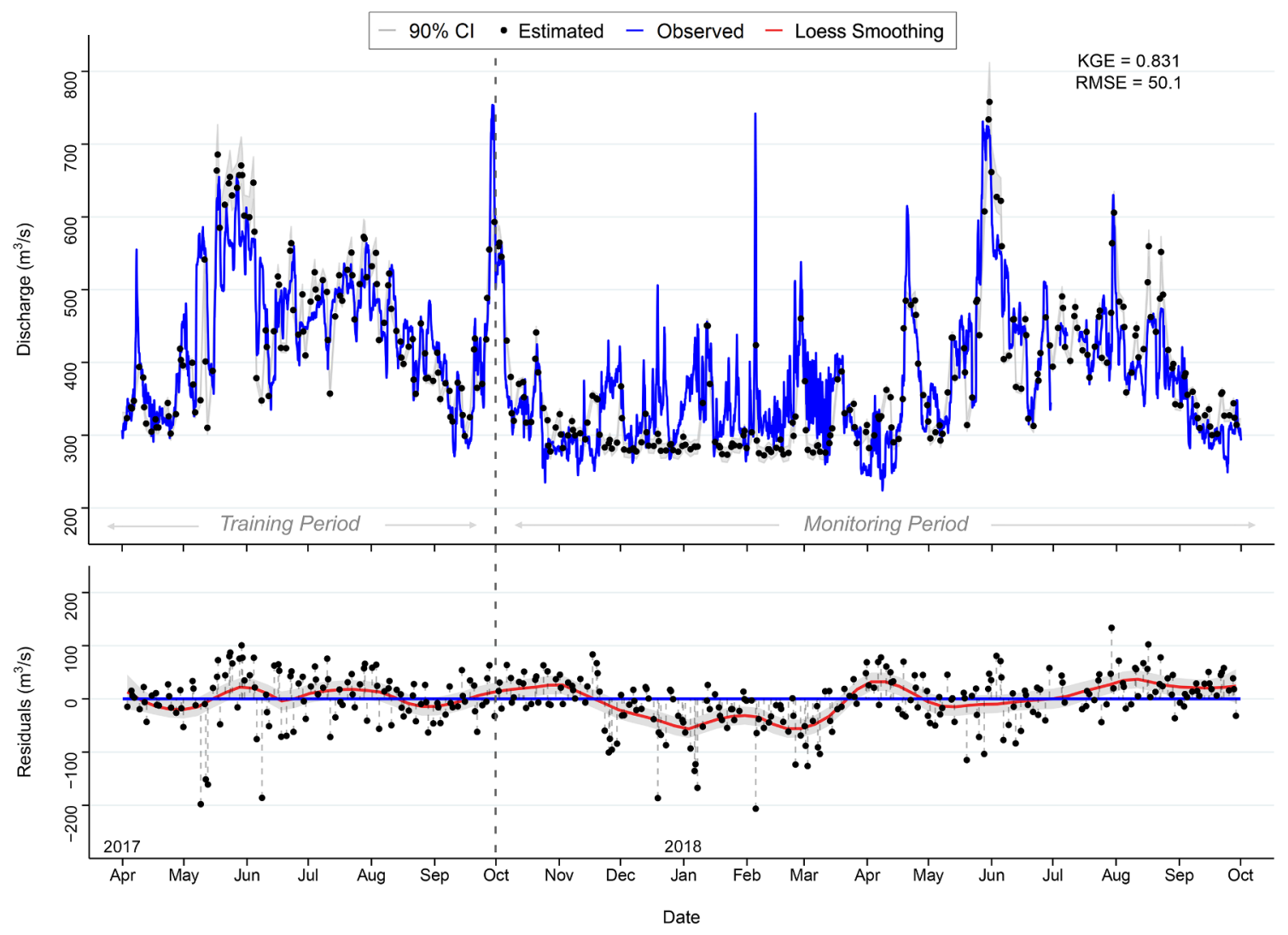

Fig. 8. The resulting discharge estimations for sub-area A1 while including the classification mask, derived by calibrating the rating curve parameters during the training period (2017/04-2017/10) and obtaining effective width observations during the monitoring period (2017/10-2018/10) (top). The residuals were derived to visualize trends in estimation errors, supported the application of Loess Smoothing (bottom) (Wickham, 2016). 
L-band radar platform with both high temporal and high spatial resolution is available.

\subsection{Classification mask}

We showed that a Sentinel-2 based classification mask, which is used to classify areas of stable water and stable land, is important to obtain accurate discharge estimates derived from dense Sentinel-1 backscatter observations (Table 3 and Fig. 7). When excluding the classification mask, the KGE of the estimated discharge decreased to a maximum value of 0.4 , which at best only explains the large scale discharge patterns on a long time scale. The histogram of the MNDWI showed a clear trimodal distribution (Fig. 4). However, one should consider that such a clearly distributed histogram might not always be acquired. In such cases other methods like Otsu's algorithm could be considered (Otsu, 1979). The threshold values which divided the MNDWI into areas of fixed and variable land cover were derived by calculating the mean MNDWI of the entire water and land clusters. This method should be reproducible for other study areas with different histograms, but the quality of the classification mask is not guaranteed. Therefore, more research is necessary to delineate a reproducible and universal method for generating a classification mask based on fixed and variable land cover classifications. A step forward could be the implementation of a high resolution $(\leq 10 \mathrm{~m}$ ) Digital Elevation Model (DEM). A DEM could be used to mask areas based on their slope and relative height compared to the river. However, especially braided rivers are known for changing their course frequently over time. Therefore, one could ask at what point a DEM becomes outdated due to the formation of new gullies or the complete change of the course of the river. For this issue a DEM such as the ArticDEM could be a solution, due to its multi-temporal nature (Barr et al., 2018; Dai et al., 2018). For future research we therefore recommend the use of such a multi-temporal DEM in conjunction with a Sentinel-2 (or any other high resolution optical satellite) based classification mask.

\subsection{Discharge estimation}

In this research we showed that both for the training period and for the monitoring period the discharge could be accurately estimated on a near-daily basis (Figs. 7 and 8). Although there is still need for in situ discharge observations to calibrate the rating curve, these remote sensing based discharge estimations can become a welcome addition next to in situ observations. Our results show that the discharge estimations for the winter period significantly decreased in accuracy (Fig. 8). Most observed discharge peaks were not represented by the estimated discharge. However, the most prominent divergent pattern was not found when looking at the estimated discharge, but could be found for the in situ discharge observations. Fig. 9 shows that between 2017/12/25 and 2018/01/06 the observed discharge increases constantly. However, such an increase in discharge is not a natural precipitation, groundwater, or ablation induced process, but is presumably caused by the formation of a freeze-up ice-jam, a common phenomenon in Icelandic rivers (Pagneux et al., 2010, 2011), formed in the vicinity of the gauging station. As mentioned earlier, the bjórsá itself is known for developing ice-jams at the location of the observation station V320 (Fig. 2) every year and some records even indicate a water-level increase of $18 \mathrm{~m}$ during such events (Eliasson and Gröndal, 2008). The large discharge peak in February, shown in Fig. 9, could indicate the presence of a dynamic ice-jam, due to the rapid increase in discharge and the height of the discharge peak. Due to such ice-jam events, the uncorrected in situ discharge observations might not always be reliable, indicating the vulnerability of some in situ discharge observations. However, because our remote sensing based discharge product is not based on the observations at the location of the ice-jam, but at a much wider section of the river roughly $15 \mathrm{~km}$ upstream, the impact of icejams on the water-level, and thus the estimated discharge, should be
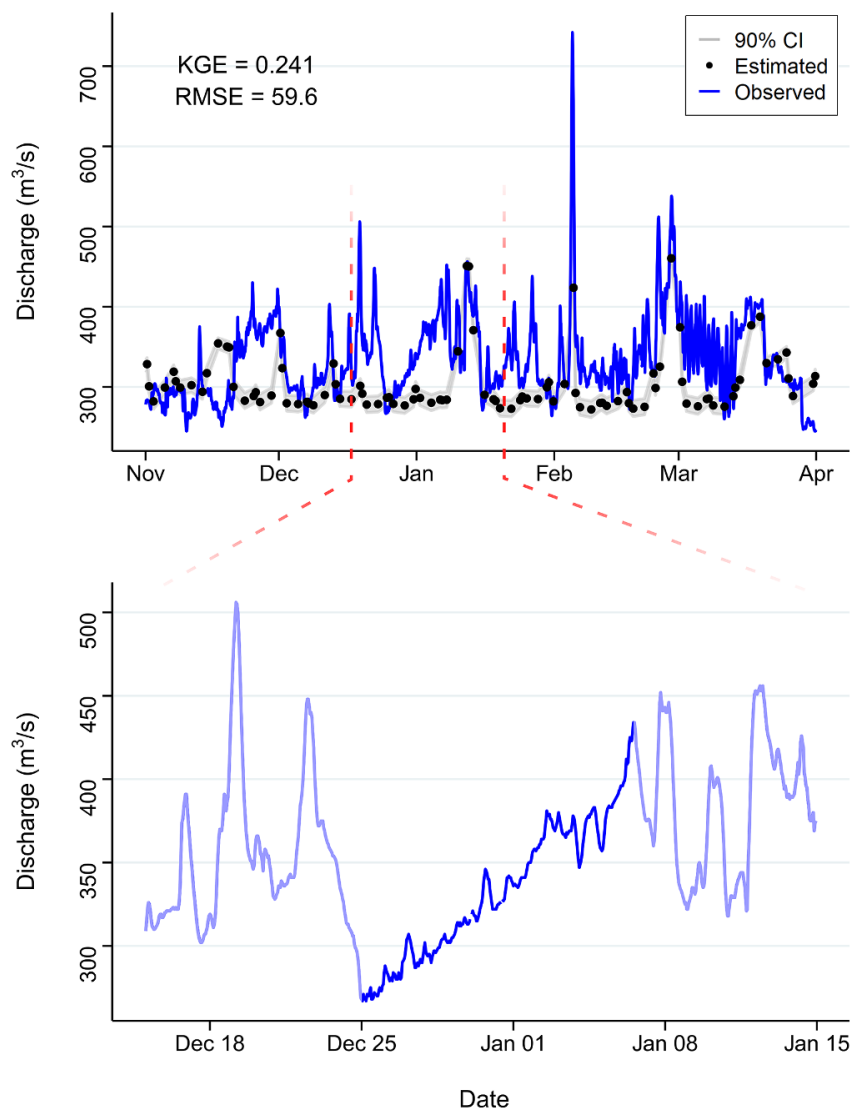

Fig. 9. The estimated and observed discharge for the winter of the monitoring period (top) and the original discharge observations with a one-hour time interval for the period between $2017 / 12 / 15$ and 2018/01/15 to investigate the presence of an ice-jam (bottom).

less dramatic. This could be a benefit of using remote sensing based discharge estimations instead of in situ observations during ice-jam events. Although, the height difference between the gauging station and sub-area A1 is roughly $20 \mathrm{~m}$, it is unknown how much our study area is influenced by backwater effects due to the ice-jam itself, which should be investigated in more detail.

Although the effect of ice-jams should be less on remote sensing based discharge estimations, snow and ice in general presumably have a negative influence on the accuracy of the water classifications and the estimated discharge. Especially ice would cause the most issues since these areas would not be classified as water, although water is still capable of flowing underneath its surface. An observed effective width in winter would thus correspond to a different discharge than during ice-free conditions. Snow does not directly increase or decrease the backscatter intensity but causes the signal to refract in the boundary between snow and air due to differences in dielectric properties (Guneriussen et al., 2001). Since there is a difference in accuracy of the estimated discharge for summer and winter, two classifiers could be trained each representing a different season. The summer model would follow the same approaches as evaluated in this research, but the winter model, where snow and ice formations become an issue, can be elaborated on the implementation of snow and ice detection. The knowledge on the presence of snow and ice can then be used to calibrate the rating curve. This way, for potentially every high-latitude catchment which does not completely freeze over, the discharge could be estimated on a near-daily basis using Sentinel-1 and 2 satellite observations.

Finally, we showed that it is possible to yield a KGE of 0.831, which is something not all hydrological models can achieve for every catchment (Finger et al., 2011; Jónsdóttir, 2008; Rögnvaldsson et al., 2007). However, in contrast to estimating the discharge when using 
hydrological models, the estimated discharge peaks cannot directly be linked to environmental conditions, but solely to the extent of the river. Mainly changes in the hydraulic geometry of a river remain difficult to monitor from space. There are many approaches for generating discharge estimations using remote sensing based observations (Alsdorf et al., 2007). However, until recently none of the satellite platforms was capable of observing at temporal and spatial resolutions of 1-3 days and $10 \mathrm{~m}$ respectively. To overcome this issue other studies have combined multiple (both altimetry and imagery based) platforms with statistical, hydraulic, or hydrological models (Brakenridge et al., 2012; Hagemann et al., 2017; Hou et al., 2018; Oubanas et al., 2018; Paris et al., 2016; Perumal et al., 2007; Poortinga et al., 2017; Sichangi et al., 2016; Sun et al., 2010; Tourian et al., 2013; Zaji et al., 2018). Combining neardaily remote sensing based river surface area and/or discharge estimations potentially increases the performance of these models. This could make remote sensing based hydrological modeling of ungauged basins become a more viable option.

\section{Conclusion}

In this research we demonstrated the potential of the Sentinel-1 and 2 satellites to generate accurate near-daily discharge estimations for a medium-sized high-latitude river. We showed that the water surface area of the Icelandic bjórsá could be accurately classified with a user's and producer's accuracy of $91.0 \%$ and $75.1 \%$ respectively. In addition, we showed that, depending on the training area, the discharge could be estimated with a high KGE up to 0.831 for a year-long monitoring period. The achievements of this research relied on multiple key factors, e.g. (i) the implementation of multiple Sentinel-1 backscatter metrics derived from the original VV and $\mathrm{VH}$ observations, which provided the Random Forest classifier with more elaborate information on the river dynamics, (ii) the implementation of the Sentinel-2 based classification mask, which reduced the amount of misclassifications at locations with little land cover change over time, and (iii) the training area selection, where we showed that sufficient river width $(100-200 \mathrm{~m})$ and the presence of gently sloping features like large isolated sandbars and inner banks are preferred. During winter the accuracy of the estimated discharge decreased. However, we also showed the vulnerability of in situ discharge observations in locations which are affected by ice-jams. Having access to near-daily discharge estimations derived from training areas which are less influenced by ice-jams is therefore valuable. Further research should test our methods for different catchments to unveil the full potential of dense Sentinel-1 and 2 observations for neardaily high-latitude discharge estimation as a valuable asset next to existing in situ discharge observations for climate change monitoring.

\section{CRediT authorship contribution statement}

Joost Brombacher: Conceptualization, Methodology, Software, Formal analysis, Investigation, Resources, Data curation, Writing original draft, Writing - review \& editing, Visualization, Supervision, Project administration. Johannes Reiche: Conceptualization, Methodology, Software, Resources, Writing original draft, Writing - review \& editing, Project administration. Roel Dijksma: Conceptualization, Methodology, Resources, Writing - original draft, Writing - review \& editing, Project administration. Adriaan J. Teuling: Methodology, Writing - original draft, Writing review \& editing.

\section{Acknowledgments}

We would like to give special thanks to Óðinn Pórarinsson, Jórunn Harðardóttir, the Icelandic Meteorological Office, and the National Power Company of Iceland for making the discharge observation dataset of the Pjórsá available for this research and its reviewers. In addition, we would like to thank the four anonymous reviewers for their constructive feedback. Finally, we would also like to thank ESA and Google for providing free access to the Sentinel-1 and Sentinel-2 data through the Google Earth Engine platform. This research contains modified Copernicus Sentinel data 2017-2018.

\section{References}

Aðalgeirsdóttir, G., Jóhannesson, T., Björnsson, H., Pálsson, F., Sigurosson, O., 2006. Response of Hofsjökull and southern Vatnajökull, Iceland, to climate change. J. Geophys. Res. Earth Surf. 111, 1-15. https://doi.org/10.1029/2005JF000388.

Abegg, B., Agrawala, C., Crick, F., de Montfalcon, A., 2007. Climate change impacts and adaptation in winter tourism. In: Agrawala, S. (Ed.), Clim. Chang. Eur. Alps Adapt. Winter Tour. Nat. Hazards, pp. 25-58.

Alsdorf, D.E., Rodríguez, E., Lettenmaier, D.P., 2007. Measuring surface water from space. Rev. Geophys. 45, 1-24. https://doi.org/10.1029/2006RG000197.

Ashmore, P., Sauks, E., 2006. Prediction of discharge from water surface width in a braided river with implications for at-a-station hydraulic geometry. Water Resour. Res. 42, 1-11. https://doi.org/10.1029/2005WR003993.

Attema, E., Bargellini, P., Edwards, P., Levrini, G., Lokas, S., Moeller, L., Rosich-Tell, B. Secchi, P., Torres, R., Davidson, M., Snoeij, P., 2007. The radar mission for GMES operational land and sea services. Eur. Sp. Agency Bull. 131, 10-17.

Bach, A.F., van der Schrier, G., Melsen, L.A., Klein Tank, A.M., Teuling, A.J., 2018. Widespread and accelerated decrease of observed mean and extreme snow depth over Europe. Geophys. Res. Lett. 45https://doi.org/10.1029/2018GL079799. 12,312-12, 319.

Banko, G., 1998. A review of assessing the accuracy of classifications of remotely sensed data and of methods including remote sensing data in forest inventory IASA Interim Report. IIASA, Laxenburg, Austria IR-98-08.

Barnett, T.P., Adam, J.C., Lettenmaier, D.P., 2005. Potential impacts of a warming climate on water availability in snow-dominated regions. Nature 438, 303-309. https://doi. org/10.1038/nature04141.

Barr, I.D., Dokukin, M.D., Kougkoulos, I., Livingstone, S.J., Lovell, H., Małecki, J., Muraviev, A.Y., 2018. Using arcticDEM to analyse the dimensions and dynamics of debris-covered glaciers in Kamchatka, Russia. Geosci. 8. https://doi.org/10.3390/ geosciences8060216.

Bauer-Marschallinger, B., Paulik, C., Schaufler, S., 2018. Copernicus global land operations "vegetation and energy". Copernicus Glob. L. Oper. 1-37 Lot1.

Bekryaev, R.V., Polyakov, I.V., Alexeev, V.A., 2010. Role of polar amplification in long term surface air temperature variations and modern arctic warming. J. Clim. 23, 3888-3906. https://doi.org/10.1175/2010JCLI3297.1.

Beltaos, S., Prowse, T.D., 2001. Climate impacts on extreme ice-jam events in Canadian rivers. Hydrol. Sci. J. 46, 157-181. https://doi.org/10.1080/02626660109492807.

Beniston, M., 2012. Impacts of climatic change on water and associated economic activities in the Swiss Alps. J. Hydrol. 412-413, 291-296. https://doi.org/10.1016/j jhydrol.2010.06.046.

Biancamaria, S., Lettenmaier, D.P., Pavelsky, T.M., 2016. The SWOT mission and its capabilities for land hydrology. Surv. Geophys. 37, 307-337. https://doi.org/10. 1007/s10712-015-9346-y.

Bjerklie, D.M., Dingman, S.L., Vorosmarty, C.J., Bolster, C.H., Congalton, R.G., 2003. Evaluating the potential for measuring river discharge from space. J. Hydrol. 278, 17-38. https://doi.org/10.1016/S0022-1694(03)00129-X.

Boschetti, M., Colombo, R., Gomarasca, M., 1998. Potential application of ERS-1 SAR data for estimating the Ticino braided river discharge. Proc. SPIE - Int. Soc. Opt. Eng. 3496, 78-85. https://doi.org/10.1117/12.332711.

Brakenridge, R., Nghiem, S.V., Anderson, E., Chien, S., 2005. Space-based measurement of river runoff. Eos, Trans. Am. Geophys. Union 86. https://doi.org/10.1029/ 2005EO190001.

Braca, G., 2008. Stage-discharge relationships in open channels: practices and problems. In: FORALPS Technical Report, 11. Università degli Studi di Trento, Dipartimento di Ingegneria Civile e Ambientale, Trento, pp. 24.

Brakenridge, R.G., Cohen, S., Kettner, A.J., De Groeve, T., Nghiem, S.V., Syvitski, J.P., Fekete, B.M., 2012. Calibration of satellite measurements of river discharge using a global hydrology model. J. Hydrol. 475, 123-136. https://doi.org/10.1016/j.jhydrol. 2012.09.035.

Breiman, L., 2001. Random forests. Mach. Learn. 45, 5-32. https://doi.org/10.1023/ A:1010933404324.

Calle, M.L., Urrea, V., 2010. Letter to the editor: stability of Random Forest importance measures. Brief. Bioinform. 12, 86-89. https://doi.org/10.1093/bib/bbq011.

Cayan, D.R., Dettinger, M.D., Caprio, J.M., Peterson, D.H., Kammerdiener, S.A., 2001. Changes in the onset of spring in the Western United States. Bull. Am. Meteorol. Soc. 82, 399-415. https://doi.org/10.1175/1520-0477(2001)082<0399:citoos > 2.3. co; 2 .

Clement, M.A., Kilsby, C.G., Moore, P., 2017. Multi-temporal synthetic aperture radar flood mapping using change detection. J. Flood Risk Manag. 11, 152-168. https:// doi.org/10.1111/jfr3.12303.

Congalton, R.G., Green, K., 2009. Assessing the Accuracy of Remotely Sensed Data: Principles and Practices, Second ed. CRC Press, Boca Raton. https://doi.org/10. 1111/j.1477-9730.2010.00574_2.x.

Cooley, S.W., Smith, L.C., Stepan, L., Mascaro, J., 2017. Tracking dynamic northern surface water changes with high-frequency Planet CubeSat Imagery. Remote Sens. 9, 1-21. https://doi.org/10.3390/rs9121306.

Dai, C., Durand, M., Howat, I.M., Altenau, E.H., Pavelsky, T.M., 2018. Estimating river surface elevation from ArcticDEM. Geophys. Res. Lett. 45, 3107-3114. https://doi. org/10.1002/2018GL077379. 
Déry, S.J., Stieglitz, M., McKenna, E.C., Wood, E.F., 2005. Characteristics and trends of river discharge into Hudson, James, and Ungava Bays, 1964-2000. J. Clim. 18, 2540-2558. https://doi.org/10.1175/JCLI3440.1.

Durand, M., Gleason, C.J., Garambois, P.A., Bjerklie, D., Smith, L.C., Roux, H., Rodriguez, E., Bates, P.D., Pavelsky, T.M., Monnier, J., Chen, X., Baldassarre, G.D., Fiset, J.-M., Flipo, N., Frasson, R.P.d.M., Fulton, J., Goutal, N., Hossain, F., Humphries, E., Minear, J.T., Mukolwe, M.M., Neal, J.C., Ricci, S., Sanders, B.F., Schumann, G., Schubert, J.E., Vilmin, L., 2016. An intercomparison of remote sensing river discharge estimation algorithms from measurements of river height, width, and slope. Water Resour. Res. 52, 4527-4549. https://doi.org/10.1002/2016WR018780. Received.

Earman, S., Campbell, A.R., Phillips, F.M., Newman, B.D., 2006. Isotopic exchange between snow and atmospheric water vapor: estimation of the snowmelt component of groundwater recharge in the southwestern United States. J. Geophys. Res. Atmos. 111, 1-18. https://doi.org/10.1029/2005JD006470.

Efron, B., 1979. Bootstrap methods: another look at the jacknife. Ann. Stat. 7, 1-26.

Eliasson, J., Gröndal, G., 2008. Development of a river ice jam by a combined heat loss and hydraulic model. Hydrol. Earth Syst. Sci. 12, 1249-1256. https://doi.org/10. 5194/hess-12-1249-2008.

ESA, 2012a. Sentinel-1 ESA's radar observatory mission for GMES operational services. ESA Spec. Publ. SP-1322/1, 1-88.

ESA, 2012b. Sentinel-2 ESA's optical high-resolution mission for GMES operational ser vices. ESA Spec. Publ. SP-1322/2, 1-70.

Fekete, B.M., Vörösmarty, C.J., 2007. The current status of global river discharge monitoring and potential new technologies complementing traditional discharge measurements. Proc. PUB Kick-off Meet. 309, 20-22.

Feyisa, G.L., Meilby, H., Fensholt, R., Proud, S.R., 2014. Automated Water extraction index: a new technique for surface water mapping using Landsat imagery. Remote Sens. Environ. 140, 23-35. https://doi.org/10.1016/j.rse.2013.08.029.

Finger, D., Pellicciotti, F., Konz, M., Rimkus, S., Burlando, P., 2011. The value of glacier mass balance, satellite snow cover images, and hourly discharge for improving the performance of a physically based distributed hydrological model. Water Resour. Res. 47, 1-14. https://doi.org/10.1029/2010WR009824.

Flowers, G.E., Marshall, S.J., Björnsson, H., Clarke, G.K., 2005. Sensitivity of Vatnajökull ice cap hydrology and dynamics to climate warming over the next 2 centuries. J. Geophys. Res. Earth Surf. 110, 1-19. https://doi.org/10.1029/2004JF000200.

Francis, J.A., Vavrus, S.J., Cohen, J., 2017. Amplified Arctic warming and mid-latitude weather: new perspectives on emerging connections. Wiley Interdiscip. Rev. Clim. Chang. 8, 1-11. https://doi.org/10.1002/wcc.474.

Gleason, C.J., Smith, L.C., 2014. Toward global mapping of river discharge using satellite images and at-many-stations hydraulic geometry. Proc. Natl. Acad. Sci. U. S. A. 111, 4788-4791. https://doi.org/10.1073/pnas.1317606111.

Google Earth Engine, 2019. Sentinel-1 SAR GRD: C-band Synthetic Aperture Radar Ground Range Detected. https://developers.google.com/earth-engine/datasets/ catalog/, Accessed date: 10 April 2019.

Goulding, H.L., Prowse, T.D., Bonsal, B., 2009. Hydroclimatic controls on the occurrence of break-up and ice-jam flooding in the Mackenzie Delta, NWT, Canada. J. Hydrol. 379, 251-267. https://doi.org/10.1016/j.jhydrol.2009.10.006.

Gudmundsson, Á., 2017. The Glorious Geology of Iceland's Golden Circle, 1st ed. Springerhttps://doi.org/10.1007/978-3-319-55152-4.

Guneriussen, T., Hogda, K.A., Johnsen, H., Lauknes, I., 2001. InSAR for estimation of changes in snow water equivalent of dry snow. IEEE Trans. Geosci. Remote Sens. 39, 2101-2108. https://doi.org/10.1109/36.957273.

Gupta, H.V., Kling, H., Yilmaz, K.K., Martinez, G.F., 2009. Decomposition of the mean squared error and NSE performance criteria: implications for improving hydrological modelling. J. Hydrol. 377, 80-91. https://doi.org/10.1016/j.jhydrol.2009.08.003.

Hagemann, M.W., Gleason, C.J., Durand, M.T., 2017. BAM: Bayesian AMHG-Manning inference of discharge using remotely sensed stream width, slope, and height. Water Resour. Res. 53, 9692-9707. https://doi.org/10.1002/2017WR021626.

Han, H., Guo, X., Yu, H., 2017. Variable selection using mean decrease accuracy and mean decrease Gini based on Random Forest. In: Proc. IEEE Int. Conf. Softw. Eng. Serv. Sci. ICSESS, pp. 219-224. https://doi.org/10.1109/ICSESS. 2016.7883053.

Hanna, E., Jónsson, T., Box, J.E., 2004. An analysis of Icelandic climate since the nineteenth century. Int. J. Climatol. 24, 1193-1210. https://doi.org/10.1002/joc.1051.

Harrelson, C.C., Rawlins, C.L., Potyondy, J.P., 1994. Stream channel reference sites: an illustrated guide to field technique. In: U.S. Forest Service, Rocky Mountain Forest and Range Experiment Station. General Techincal Report RM-245, Fort Collins, Colorado.

Herschy, R.W., 2009. Streamflow Measurement. Taylor \& Francis, London \& New York. https://doi.org/10.4324/9780203931394.

Hidayat, H., Teuling, A.J., Vermeulen, B., Taufik, M., Kastner, K., Geertsema, T.J., Bol, D.C., Hoekman, D.H., Sri Haryani, G., Van Lanen, H.A., Delinom, R.M., Dijksma, R., Anshari, G.Z., Ningsih, N.S., Uijlenhoet, R., Hoitink, A.J., 2017. Hydrology of inland tropical lowlands: the Kapuas and Mahakam wetlands. Hydrol. Earth Syst. Sci. 21, 2579-2594. https://doi.org/10.5194/hess-21-2579-2017.

Hou, J., Van Dijk, A.I.J.M., Renzullo, L.J., Vertessy, R.A., 2018. Using modelled discharge to develop satellite-based river gauging: a case study for the Amazon Basin. Hydrol. Earth Syst. Sci. 22, 6435-6448. https://doi.org/10.5194/hess-2018-261.

Hróðmarsson, H.B., pórarinsdóttir, T., 2018. Flóð íslenskra vantsfalla. Flóðagreining rennslisraða (Floods in Icelandic rivers. Frequency analysis). In: Report VÍ 2018-003. Reykjavik: Icelandic Meteorological Office.

Huang, Q., Long, D., Du, M., Zeng, C., Qiao, G., Li, X., Hou, A., Hong, Y., 2018. Discharge estimation in high-mountain regions with improved methods using multisource remote sensing: a case study of the Upper Brahmaputra River. Remote Sens. Environ. 219, 115-134. https://doi.org/10.1016/j.rse.2018.10.008.

Iceland Magazine, 2017. The bjórsá river near the Urriðafoss. https://icelandmag.is/ article/icelandic-kayaker-died-french-kayaker-saved-high-waves-estuary-thjorsariver, Accessed date: 5 February 2019.

Icelandic Energy Authority, 2006. Energy in Iceland: Historical perspective, present status, future outlook, 2nd ed.

Icelandic Meteorological Office, 2011. Map of hydrological observations in Iceland. https://en.vedur.is/hydrology/stations/bigimg/1779?ListID =0, Accessed date: 20 August 2018.

Icelandic Meteorological Office, 2018. Delivery of data from the Hydrological database. no. 2018-11-13/01. http://vmkerfi.vedur. is/vatn, Accessed date: 13 November 2018

IPCC, 2013. Climate Change 2013: The Physical Science Basis. Contribution of Working Group I to the Fifth Assessment Report of Intergovernmental Panel on Climate Change. Cambridge University Press, Cambridge (United Kingdom) \& New York (NY, USA). https://doi.org/10.1017/CBO9781107415324.

Jóhannesson, T., Aðalgeirsdóttir, G., Björnsson, H., Crochet, P., Elíasson, E.B. Guðmundsson, S., Jónsdóttir, J.F., Ólafsson, H., Pálsson, F., Rögnvaldsson, Ó. Sigurðsson, O., Snorrason, Á., Sveinsson, Ó.G.B., Thorsteinsson, T., 2007. Effect of climate change on hydrology and hydro-resources in Iceland. National Energy Authority - Hydrological Service Report No.: OS-2007/011.

Jónsdóttir, J.F., 2008. A runoff map based on numerically simulated precipitation and a projection of future runoff in Iceland. Hydrol. Sci. J. 53, 100-111. https://doi.org/10 1623/hysj.53.1.100.

Jowett, I., 1998. Hydraulic geometry of New Zealand rivers and its use as a preliminary method of habitat assessment. Regul. Rivers Res. Manag. 14, 451-466. https://doi, org/10.1002/(sici)1099-1646(1998090)14:5<451::aid-rrr512>3.3.co;2-t.

Ju, J., Roy, D.P., 2008. The availability of cloud-free Landsat ETM + data over the conterminous United States and globally. Remote Sens. Environ. 112, 1196-1211. https://doi.org/10.1016/j.rse.2007.08.011.

Koblinsky, C.J., Clarke, R.T., Brenner, A.C., Frey, H., 1993. Measurement of river level variations with satellite altimetry. Water Resour. Res. 29, 1839-1848. https://doi. org/10.1029/93WR00542.

Kundzewicz, Z., Mata, L., Arnell, N., Döll, P., Kabat, P., Jiménez, B., Miller, K., Oki, T., Sen, Z., Shiklomanov, I., 2007. Freshwater resources and their management. In: Clim. Chang. 2007 Impacts, Adapt. Vulnerability. Contrib. Work. Gr. II to Fourth Assess. Rep. Intergov. Panel Clim. Chang. pp. 173-210.

Landsvirkjun, 2018. Hydropower Stations in the Thjórsá Catchment. https://www. landsvirkjun.com/Company/PowerStations/SigaldaPowerStation/, Accessed date: 25 January 2019.

Lee, J.-S., 1986. Speckle suppression and analysis for synthetic aperture radar images. Opt. Eng. 25, 636-643. https://doi.org/10.1117/12.949537.

Lemoine, G., 2017. Source Code of Refined Sigma Lee Speckle Filter. https://code. earthengine.google.com/2ef38463ebaf5ae133a478f173fd0ab5, Accessed date: 31 October 2018.

Leopold, L.B., Maddock, T., 1953. The hydraulic geometry of stream channels and some physiographic implications. United States Geol. Surv. Prof. Pap. 252, 1-57. https:// doi.org/10.17485/ijst/2016/v9i27/97597.

Leopold, L., Wolman, M., Millar, J., 1995. Fluvial Processes in Geomorphology. Courier Dover Publications, New York.

Li, J., Yesou, H., Malosti, R., Andreoli, R., Huang, S., Xin, J., Cattaneo, F., 2008. Near real time flood monitoring in P.R. China during the 2005 and 2006 flood and typhoons seasons based on Envisat ASAR medium and high resolution images. In: Proc. "Envisat Symposium 2007. ESA SP-636, Montreux, Switzerland, pp. 23-27 April 2007.

Liaw, A., Wiener, M., 2002. Classification and regression by randomForest. R News 2 , 18-22. https://cran.r-project.org/doc/Rnews/.

Lu, X.X., Zhang, S., Xu, J., 2010. Climate change and sediment flux from the roof of the world. Earth Surf. Process. Landforms 35, 732-735. https://doi.org/10.1002/esp. 1924.

MacQueen, J., 1967. Some methods for classification and analysis of multivariate observations. In: Proc. Fifth Berkeley Symp. Math. Stat. Probab. pp. 281-297. https:// doi.org/10.1007/s11665-016-2173-6.

Manakos, I., Kordelas, G.A., Marini, K., 2019. Fusion of Sentinel-1 data with Sentinel-2 products to overcome non-favourable atmospheric conditions for the delineation of inundation maps. Eur. J. Remote Sens. 1-14. https://doi.org/10.1080/22797254. 2019.1596757.

McFeeters, S.K., 2013. Using the Normalized Difference Water Index (NDWI) within a geographic information system to detect swimming pools for mosquito abatement: a practical approach. Remote Sens. 5, 3544-3561. https://doi.org/10.3390/ rs5073544.

Mertes, L.A.K., 1997. Documentation and significance of the perirheic zone on inundated floodplains. Water Resour. Res. 33, 1749-1762. https://doi.org/10.1029/ 97WR00658.

Milzow, C., Krogh, P.E., Bauer-Gottwein, P., 2011. Combining satellite radar altimetry, SAR surface soil moisture and GRACE total storage changes for hydrological model calibration in a large poorly gauged catchment. Hydrol. Earth Syst. Sci. 15, 1729-1743. https://doi.org/10.5194/hess-15-1729-2011.

Ólafsdóttir, S.R., Ólafsson, J., 1999. Input of dissolved constituents from River Thjórsá to S-Iceland coastal waters. Rit Fiskid. 16, 79-88.

Osterkamp, T.E., 2007. Characteristics of the recent warming permafrost in Alaska. J. Geophys. Res. 112, 1-10. https://doi.org/10.1029/2006JF000578.

Otsu, N., 1979. A Threshold Selection Method from Gray-Level Histograms. IEEE Trans. Syst. Man. Cybern. SMC-9, 62-66. https://doi.org/10.1109/TSMC.1979.4310076.

Oubanas, H., Gejadze, I., Malaterre, P., Durand, M., Wei, R., Frasson, R., Domeneghetti, A., 2018. Discharge estimation in ungauged basins through variational data assimilation: the potential of the SWOT mission. Water Resour. Res. 54, 2405-2423. https://doi.org/10.1002/2017WR021735.

Pagneux, E., Gísladóttir, G., Snorrason, Á., 2010. Inundation extent as a key parameter for 
assessing the magnitude and return period of flooding events in southern Iceland. Hydrol. Sci. J. 55, 704-716. https://doi.org/10.1080/02626667.2010.489281.

Pagneux, E., Gísladóttir, G., Jónsdóttir, S., 2011. Public perception of flood hazard and flood risk in Iceland: a case study in a watershed prone to ice-jam floods. Nat. Hazards 58, 269-287. https://doi.org/10.1007/s11069-010-9665-8.

Paris, A., de Paiva, R.D., da Silva, J.S., Moreira, D.M., Calmant, S., Garambois, P.-A., Collischonn, W., Bonnet, M.-P., Seyler, F., 2016. Stage-discharge rating curves based on satellite altimetry and modeled discharge in the Amazon basin. Water Resour. Res. 52, 3787-3814. https://doi.org/10.1002/2014WR016618.Received.

Park, C.C., 1977. World-wide variations in hydraulic geometry exponents of stream channels: an analysis and some observations. J. Hydrol. 33, 133-146. https://doi. org/10.1016/0022-1694(77)90103-2.

Pavelsky, T.M., 2014. Using width-based rating curves from spatially discontinuous satellite imagery to monitor river discharge. Hydrol. Process. 28, 3035-3040. https:// doi.org/10.1002/hyp.10157.

Perumal, M., Moramarco, T., Sahoo, B., Barbetta, S., 2007. A methodology for discharge estimation and rating curve development at ungauged river sites. Water Resour. Res. 43. https://doi.org/10.1029/2005WR004609.

Peterson, B.J., Holmes, R.M., McClelland, J.W., Vörösmarty, C.J., Lammers, R.B. Shiklomanov, A.I., Shiklomanov, I.A., Rahmstorf, S., 2002. Increasing river discharge to the Arctic Ocean. Science 298, 2171-2173. https://doi.org/10.1126/science. 1077445.

Poortinga, A., Bastiaanssen, W., Simons, G., Saah, D., Senay, G., Fenn, M., Bean, B., Kadyszewski, J., 2017. A self-calibrating runoff and streamflow remote sensing model for ungauged basins using open-access earth observation data. Remote Sens. 9, 1-14. https://doi.org/10.3390/rs9010086.

Probst, P., Rizzi, R., Tosi, E., Lucarini, V., Maestri, T., 2012. Total cloud cover from satellite observations and climate models. Atmos. Res. 107, 161-170. https://doi.org/ 10.1016/j.atmosres.2012.01.005.

Qiao, C., Luo, J., Sheng, Y., Shen, Z., Zhu, Z., Ming, D., 2012. An adaptive water extraction method from remote sensing image based on NDWI. J. Indian Soc. Remote Sens. 40, 421-433. https://doi.org/10.1007/s12524-011-0162-7.

Radoux, J., Bogaert, P., 2017. Good practices for object-based accuracy assessment. Remote Sens. 9, 1-23. https://doi.org/10.3390/rs9070646.

Rhoads, B.L., 1991. A continuously varying parameter model of downstream hydraulic geometry. Water Resour. Res. 27, 1865-1872. https://doi.org/10.1029/91WR01363.

Rögnvaldsson, Ó., Jónsdóttir, J.F., Ólafsson, H., 2007. Numerical simulations of precipitation in the complex terrain of Iceland - comparison with glaciological and hydrological data. Meteorol. Zeitschrift 16, 71-85. https://doi.org/10.1127/09412948/2007/0174.

Sammut, C., Webbs, G.I., 2011. Encyclopedia of Machine Learning. Springer Science + Business Media, New York. https://doi.org/10.1007/978-0-387-30164-8.

Serreze, M.C., Walsh, J.E., Chapin III, F.S., Osterkamp, T., Dyurgerov, M., Romanovsky, V., Oechel, W.C., Mosrison, J., Zhang, T., Barry, R.G., 2000. Observational evidence of recent change in the northern-high-latitude environment. Clim. Chang. 46, 159-207. https://doi.org/10.1126/science.1155121.

Shen, X., Anagnostou, E.N., Allen, G.H., Robert Brakenridge, G., Kettner, A.J., 2019. Nearreal-time non-obstructed flood inundation mapping using synthetic aperture radar. Remote Sens. Environ. 221, 302-315. https://doi.org/10.1016/j.rse.2018.11.008.

Sichangi, A.W., Wang, L., Yang, K., Chen, D., Wang, Z., Li, X., Zhou, J., Liu, W., Kuria, D., 2016. Estimating continental river basin discharges using multiple remote sensing data sets. Remote Sens. Environ. 179, 36-53. https://doi.org/10.1016/j.rse.2016.03. 019.

Smith, L.C., 1997. Satellite remote sensing of river inundation area, stage, and discharge: a review. Hydrol. Process. 11, 1427-1439. https://doi.org/10.1002/(SICI)10991085(199708)11:10<1427::AID-HYP473 > 3.3.CO;2-J.

Smith, L.C., Pavelsky, T.M., 2008. Estimation of river discharge, propagation speed, and hydraulic geometry from space: Lena River, Siberia. Water Resour. Res. 44, 1-11.
https://doi.org/10.1029/2007WR006133.

Smith, L.C., Isacks, B., Bloom, A., 1996. Estimation of discharge from three braided rivers using synthetic aperture radar satellite imagery: potential application to ungauged basins. Water Resour. Res. 32, 2021-2034. https://doi.org/10.1029/96WR00752.

Strobl, C., Boulesteix, A.L., Kneib, T., Augustin, T., Zeileis, A., 2008. Conditional variable importance for random forests. BMC Bioinf. 9. https://doi.org/10.1186/1471-21059-307.

Sun, W., Ishidaira, H., Bastola, S., 2010. Towards improving river discharge estimation in ungauged basins: Calibration of rainfall-runoff models based on satellite observations of river flow width at basin outlet. Hydrol. Earth Syst. Sci. 14, 2011-2022. https:// doi.org/10.5194/hess-14-2011-2010.

Sun, W., Fan, J., Wang, G., Ishidaira, H., Bastola, S., Yu, J., Fu, Y., Kiem, A., Zuo, D., Xu, Z., 2018. Calibrating a hydrological model in a regional river of the Qinghai-Tibet plateau using river water width determined from high spatial resolution satellite images. Remote Sens. Environ. 214, 100-114. https://doi.org/10.1016/j.rse.2018. 05.020 .

Tarpanelli, A., Brocca, L., Lacava, T., Melone, F., Moramarco, T., Faruolo, M., Pergola, N., Tramutoli, V., 2013. Toward the estimation of river discharge variations using MODIS data in ungauged basins. Remote Sens. Environ. 136, 47-55. https://doi.org/ 10.1016/j.rse.2013.04.010.

Tavares, P.A., Beltrão, N.E.S., Guimarães, U.S., Teodoro, A.C., 2019. Integration of Sentinel-1 and Sentinel-2 for classification and LULC mapping in the urban area of Belém, eastern Brazilian Amazon. Sensors 19, 1-20. https://doi.org/10.3390/ s19051140.

Torres, R., Snoeij, P., Geudtner, D., Bibby, D., Davidson, M., Attema, E., Potin, P., Rommen, B.Ö., Floury, N., Brown, M., Traver, I.N., Deghaye, P., Duesmann, B., Rosich, B., Miranda, N., Bruno, C., L'Abbate, M., Croci, R., Pietropaolo, A., Huchler, M., Rostan, F., 2012. GMES Sentinel-1 mission. Remote Sens. Environ 120, 9-24. https://doi.org/10.1016/j.rse.2011.05.028.

Tourian, M.J., Sneeuw, N., Bárdossy, A., 2013. A quantile function approach to discharge estimation from satellite altimetry (ENVISAT). Water Resour. Res. 49, 4174-4186. https://doi.org/10.1002/wrcr.20348.

Tuozzolo, S., Lind, G., Overstreet, B., Mangano, J., Fonstad, M., Hagemann, M., Frasson, R.P.M., Larnier, K., Garambois, P.-A., Monnier, J., Durand, M., 2019. Estimating rive discharge with swath altimetry: a proof of concept using AirSWOT observations. Geophys. Res. Lett. https://doi.org/10.1029/2018GL080771.

Wickham, H., 2016. ggplot2: Elegant Graphics for Data Analysis. Springer New York. http://ggplot2.org.

Willmott, C.J., Matsuura, K., 2005. Advantages of the mean absolute error (MAE) over the root mean square error (RMSE) in assessing average model performance. Clim. Res. 30, 79-82. https://doi.org/10.3354/cr00799.

$\mathrm{Xu}, \mathrm{H} ., 2006$. Modification of normalised difference water index (NDWI) to enhance open water features in remotely sensed imagery. Int. J. Remote Sens. 27, 3025-3033. https://doi.org/10.1080/01431160600589179.

Xu, K., Zhang, J., Watanabe, M., Sun, C., 2004. Estimating river discharge from very highresolution satellite data: a case study in the Yangtze River, China. Hydrol. Process. 18, 1927-1939. https://doi.org/10.1002/hyp.1458.

Yang, X., Zhao, S., Qin, X., Zhao, N., Liang, L., 2017. Mapping of urban surface water bodies from sentinel-2 MSI imagery at $10 \mathrm{~m}$ resolution via NDWI-based image sharpening. Remote Sens. 9, 1-19. https://doi.org/10.3390/rs9060596.

Yommy, A.S., Liu, R., Wu, S., 2015. SAR image despeckling using refined lee filter. In: 2015 7th Int. Conf. Intell. Human-Machine Syst. Cybern. pp. 260-265. https://doi. org/10.1109/IHMSC.2015.236.

Zaji, A.H., Bonakdari, H., Gharabaghi, B., 2018. Remote sensing satellite data preparation for simulating and forecasting river discharge. IEEE Trans. Geosci. Remote Sens. 1-10. https://doi.org/10.1109/TGRS.2018.2799901.

Zufelt, J.E., Ettema, R., 2000. Fully coupled model of ice-jam dynamics. J. Cold Reg. Eng. $14,24-41$ 